\title{
DESAFÍOS \\ ÉTICOS \\ EN LOS NEGOCIOS
}

Cesare Del Mastro Puccio

Editor

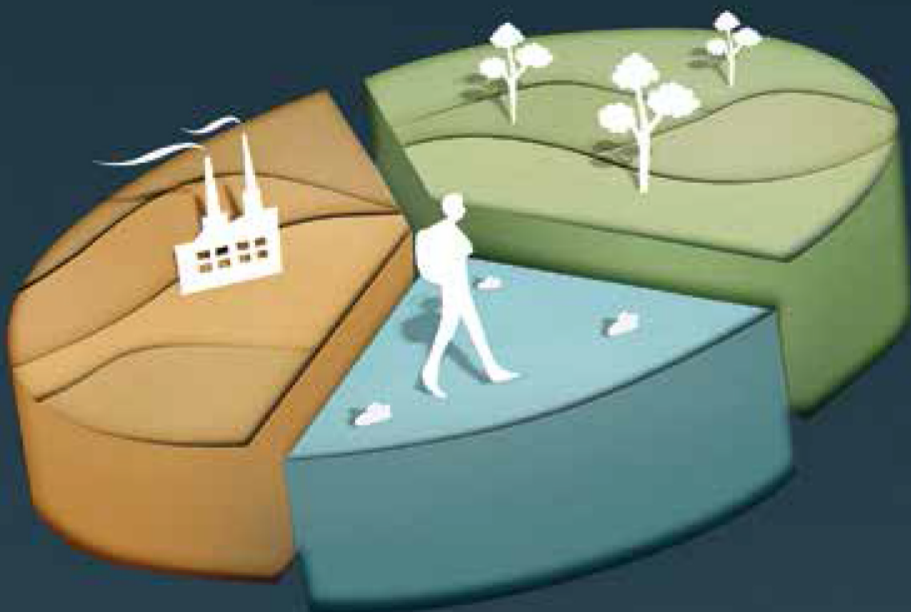

UNIVERSIDAD 



\section{Desafíos Éticos EN LOS NEgocios}

Cesare Del Mastro Puccio

Editor

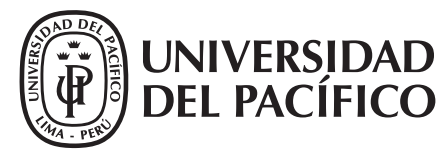


(C) Universidad del Pacífico

Av. Salaverry 2020

Lima 11, Perú

www.up.edu.pe

\section{Desafíos éticos en los negocios}

Cesare Del Mastro Puccio (editor)

Serie Conferencias 15

$1^{a}$ edición: octubre 2014

Diseño de la carátula: Icono Comunicadores

ISBN: 978-9972-57-302-6

doi: http://dx.doi.org/10.21678/978-9972-57-302-6

Hecho el Depósito Legal en la Biblioteca Nacional del Perú: 2014-14999

BUP

Desafíos éticos en los negocios / Cesare Del Mastro Puccio, editor. -- 1a edción. -Lima : Universidad del Pacífico, 2014.

$107 \mathrm{p}$.

1. Ética de los negocios

2. Publicidad -- Aspectos morales y éticos

3. Industria minera -- Aspectos morales y éticos

I. Del Mastro Puccio, Cesare, editor.

II. Universidad del Pacífico (Lima)

174.4 (SCDD)

La Universidad del Pacífico es miembro de la Asociación Peruana de Editoriales Universitarias y de Escuelas Superiores (Apesu) y de la Asociación de Editoriales Universitarias de América Latina y el Caribe (Eulac).

La Universidad del Pacífico no se solidariza necesariamente con el contenido de los trabajos que publica. Prohibida la reproducción total o parcial de este texto por cualquier medio sin permiso de la Universidad del Pacífico.

Derechos reservados conforme a ley. 


\section{Índice}

\section{Introducción}

José Piedra Valdez S. J.

Ética de las capacidades y desarrollo humano en las empresas Cristina Calvo

Ética y publicidad comercial

Crítica al engaño y a la persuasión irracional en la publicidad comercial

Alonso Villarán

La autorregulación en la publicidad comercial

Rodolfo León

Ética, minería y ambiente

Una propuesta para el análisis de conflictos sociales en términos de deliberación, agencia y reconocimiento. El caso de la minería en el Perú

Gianfranco Casuso

Minería e inversión social en turismo. Miradas desde la ética, el desarrollo y la sostenibilidad

Carlo Brescia y Viviana Quea

Siglas usadas 



\section{Introducción}

Para cada uno de nosotros, buena parte de nuestro quehacer transcurre en el afán de darle sentido a nuestra vida: vida y sentido se buscan. En esta búsqueda, tiene un lugar central la reflexión sobre los cursos de acción que tomamos en ámbitos como el profesional. Por ello, la universidad no puede limitarse a ofrecer profesionales al mercado laboral; en su proceso de aprendizaje, cada futuro profesional debe reforzar sus valores. De este modo, educamos para contribuir con la formación de buenos ciudadanos con principios y criterios para las decisiones que deberán afrontar en el futuro.

En las dos últimas décadas, el país ha crecido y se ha transformado. El crecimiento económico se ha visto interpelado por nuevos desafíos y prácticas que antes no estaban presentes en el mundo empresarial. $\mathrm{Al}$ mismo tiempo, en estos años hemos sido más conscientes de la relación entre la empresa privada y la sociedad civil: los puntos de encuentro (por ejemplo, las asociaciones público-privadas) y también los conflictos sociales nos han mostrado el valor del diálogo. Este hecho ha promovido un conjunto de buenas prácticas que han sido asumidas en el mundo empresarial. En primer lugar, constatamos la creciente importancia de los códigos de ética en las empresas, los cuales buscan regular y promover las buenas prácticas en distintos ámbitos de los negocios. En segundo lugar, se habla cada vez más del buen gobierno corporativo, modelo que defiende el manejo transparente de las organizaciones. En tercer lugar, el 
microcrédito se ha expandido notablemente tanto a partir de la banca cuanto de las instituciones sociales. En cuarto lugar, la responsabilidad social se ha convertido en un elemento imprescindible en toda empresa que pretenda ser sensible a lo que viven sus trabajadores y las personas e instituciones con las que interactúa. Es claro, por último, que las empresas se ven interpeladas por problemas ecológicos vinculados, entre otros aspectos, a la huella de carbono y al uso de residuos sólidos.

Sin embargo, es evidente que tenemos desafíos por seguir enfrentando. Es necesario, por ejemplo, trabajar por una banca más transparente, que permita al cliente saber en qué y con quién se invierte su dinero; campañas como «Hablemos claro» hacen esfuerzos en este sentido. Urge también colaborar con la educación y el consumo responsable, ya que los seres humanos no viven únicamente para consumir productos en el mercado. Asimismo, es importante asumir el vínculo fundamental que existe entre empresa y ciudadanía: los ciudadanos y el Estado deben reconocer a la empresa como parte de la comunidad y la empresa misma debe asumirse como tal. Finalmente, debemos promover una estrecha relación entre las empresas y el respeto y la promoción de los derechos humanos para que se tomen en cuenta los derechos y obligaciones de los trabajadores, en particular en la producción informal y en el manejo de los medios de comunicación.

En este contexto, la Universidad del Pacífico creó, en enero de 2013, el Centro de Ética Aplicada con la misión de promover la incorporación de la dimensión ética en el ejercicio profesional mediante el desarrollo de actividades formativas y de investigación y difusión vinculadas a necesidades y problemas actuales. Para responder a esta misión se definieron cuatro objetivos:

A. Colaborar con la formación de profesionales preocupados por la incorporación de valores y principios morales en su actuar así como por la atención a cuestiones éticas que afectan a la sociedad contemporánea peruana y mundial. 
B. Contribuir con el debate en torno a los dilemas y desafíos éticos de los profesionales que toman decisiones en las organizaciones privadas y públicas de nuestro país y de la región.

C. Generar espacios de diálogo interdisciplinario y de reflexión crítica en la búsqueda del bien común y de una sociedad más justa, en la que se promueva la participación de los diversos grupos de influencia: comunidad en general, líderes de organizaciones, comunidad empresarial, profesores, ex alumnos y alumnos.

D. Promover una cultura centrada en el comportamiento ético al interior de nuestra universidad.

Con la esperanza de crear una red de personas interesadas en reflexionar sobre los desafíos éticos que se presentan en el mundo de la empresa desde la perspectiva de la ética de las capacidades y del desarrollo humano, nuestro Primer Foro de Ética Aplicada reunió, el 29 de agosto de 2013, a académicos y empresarios interesados en los dilemas éticos que deben enfrentar, en la actualidad, quienes trabajan en negocios vinculados a la publicidad comercial y a la minería. Lejos de la simple especialización, este foro ha querido reafirmar el carácter colaborativo e interdisciplinario de la reflexión ética: las distintas formaciones y experiencias de nuestros ponentes dan testimonio de ello.

En el texto correspondiente a la charla magistral con la que iniciamos nuestro foro, la doctora Cristina Calvo, directora del Programa Internacional sobre Democracia, Sociedad y Nuevas Economías de la Universidad de Buenos Aires, presentó el marco general desde el que pretendemos orientar nuestra reflexión sobre la ética y la empresa, a saber: la ética de las capacidades y el enfoque del desarrollo humano. Siguieron a este enfoque general dos mesas de ponencias concentradas en los desafíos éticos que se presentan en dos ámbitos concretos: la publicidad y la minería. En el primer ámbito, los artículos de Alonso Villarán, docente e investigador de la Escuela de Postgrado de la Universidad del Pacífico, y de Rodolfo León, director ejecutivo de la Asociación Nacional de Anunciantes, subrayan la necesidad de que los publicistas tomen conciencia de la imagen del ser 
José Piedra Valdez S. J.

humano que ofrecen y propongan criterios y códigos de ética que permitan contar con una publicidad no manipuladora y justa en su oferta. En el segundo ámbito, Gianfranco Casuso, docente e investigador del Departamento de Humanidades de la Pontificia Universidad Católica del Perú, y Carlo Brescia y Viviana Quea, el primero director de la Asociación Civil Vasos Comunicantes y ambos consultores en desarrollo sostenible, desarrollan marcos conceptuales sobre las complejas relaciones entre el ser humano y la naturaleza para ayudarnos a comprender las motivaciones profundas de los conflictos medioambientales que se viven en el país. Ellos comparten también experiencias y pistas de acción para recrear los vínculos entre medio ambiente, comunidad, empresa y Estado desde un enfoque del desarrollo humano marcado por el reconocimiento, la sostenibilidad y la búsqueda del bien común.

En el mundo empresarial la buena reputación se vuelve un valor. Sabemos que confianza o engaño pueden promover o estancar una actividad económica. ¿Qué hay detrás? ¿Qué puede fallar? No nos pueden bastar las sanciones ni los códigos de ética: hemos de volver a la conciencia, ese fondo del ser humano que nos lleva a reconocer si hemos hecho algo equivocado o correcto. Proyectado a un nivel mayor, esto nos puede conducir a una conciencia ética que guíe nuestros proyectos colectivos nacionales. Pero ello exige un esfuerzo considerable de diálogo y consenso. La publicación de las actas del Primer Foro de Ética Aplicada busca, pues, abrir espacios de diálogo en los que se integren reflexión ética y práctica empresarial. Estamos de acuerdo en que el mercado debe ser eficiente, pero creemos que también debe ser justo. Hemos de contar con un mercado que ponga en el centro de su actividad a la persona, lejos de la búsqueda exclusiva y excluyente de los propios intereses. Estamos convencidos de que la ética contribuirá a que los distintos actores sociales, enfrentados hoy en diversos tipos de conflictos, puedan entrar en un proceso de diálogo fructífero.

José Piedra Valdez S. J. Director del Centro de Ética Aplicada Universidad del Pacífico 


\title{
Ética de las capacidades y desarrollo humano en las empresas
}

\author{
Cristina Calvo \\ Universidad de Buenos Aires
}

\section{Premisa}

¿Cómo es un mundo sostenible? ¿Cómo podemos hacerlo realidad? ¿Qué roles pueden asumir las empresas para asegurar un más rápido progreso hacia dicho mundo?

La respuesta a estas preguntas requiere, sin duda, la interacción entre empresa, sociedad civil y gobierno respecto a cómo alcanzar un futuro sostenible. Por eso, el tipo de empresa al cual me referiré corresponde a una concepción que hoy considero ineludible, a saber: la de la empresa que se juega en el espacio de lo público -diferente de lo estatal- y dirigida al interés común, es decir, orientada a contribuir con la generación de condiciones de vida digna para el conjunto de la sociedad. La finalidad de la empresa, de hecho, no es simplemente la generación de utilidades, sino más bien su existencia misma como comunidad de personas que, de distintas formas, persiguen la satisfacción de sus necesidades fundamentales y constituyen un particular grupo al servicio de toda la sociedad. 
En febrero de 2011, Michael Porter, profesor de la Harvard Business School, afirmó lo siguiente: «El sistema capitalista está sitiado. En los últimos años, el comercio fue considerado, cada vez en mayor medida, la causa de problemas sociales, ambientales y económicos. Y gran parte de la población cree que las empresas prosperaron a expensas de la comunidad» (La Nación 2013: 1-2). En efecto, el actual modelo de negocios perdió confianza y legitimidad en la sociedad, razón por la cual debe reinventarse para que pueda ser realmente sustentable. No pensemos en filantropía o en responsabilidad social empresarial (RSE) entendida como una función marginal o anexa a la empresa. Se trata, por el contrario, de reinventar el mismo «corazón de los negocios» a través de la creación simultánea de valor económico y de valor social. La idea de fondo, en definitiva, es que las acciones pasen a ser una consecuencia natural de la manera de vivir la misión empresarial (La Nación 2013: 1-2).

\section{Hacia qué mundo podemos ir}

Nunca, como hasta ahora, el futuro había dependido tanto de lo que hoy hagamos todos: empresas, ciudadanos y gobiernos. En efecto, cuando realizamos diagnósticos pensamos en «lo que será» y tememos que se verifiquen ciertos diagnósticos. Lo que más importa es, pues, «hacia dónde queremos ir». No se pueden soslayar, en este sentido, las consecuencias del cambio climático, del crecimiento demográfico y de la urbanización, pero sí podemos ofrecer la mejor perspectiva posible para las personas y para el planeta en las próximas décadas. En el año 2050, seremos unos 9.000 millones de personas: ¿podrán desarrollarse estas con un nivel de vida aceptable acorde con los límites del planeta? Para que en ese año dicha cantidad de personas no solo puedan vivir en el planeta sino que «vivan bien», se debe desarrollar una hoja de ruta hacia la sostenibilidad. Con la expresión «vivir bien» nos referimos a un nivel de vida que permita a la gente tener medios para costearse la educación, la salud, la movilidad y las necesidades básicas de alimento, agua, energía y vivienda. No obstante, los «límites del planeta» son inseparables de lo 
anterior: se trata de poder vivir bien sin seguir dañando la biodiversidad y la naturaleza. Los líderes empresariales, los gobernantes y la sociedad civil tenemos que tomar decisiones que permitan conseguir los mejores resultados posibles para la vida digna ${ }^{1}$.

En lugar de ir a la zaga del cambio, las empresas deberían encabezar esta transformación llevando a cabo lo que mejor saben hacer: crear las soluciones rentables que las personas necesiten y deseen. La diferencia consiste en que ahora habrá que pensar las soluciones a través de la determinación de su valor y de su costo real, según supongan o no vivir coherentemente dentro de los límites del planeta. Para ello, las empresas deberán trabajar en estrecha colaboración con los gobiernos y las organizaciones civiles por medio del pensamiento y de la planificación sistémica. Entonces, no es sencillo afirmar que en el año 2050 « 9.000 millones de personas vivirán bien pero dentro de los límites del planeta». En efecto, si seguimos produciendo y consumiendo como lo hacemos hoy, vamos a necesitar 2,3 planetas Tierra para obtener agua, fibra, energía y alimentos. ¿Por qué? Porque, en este momento, están conviviendo una «agenda de abundancia/exceso» y una «agenda de restricciones/límites del planeta».

Ocurre que $85 \%$ de esos 9.000 millones va a vivir en países en desarrollo (emergentes) como los nuestros. Vamos a ser más y a estar más «apretados», porque $70 \%$ de la economía del mundo hacia el año 2050 vendrá de países como los nuestros y no únicamente de China e India. En este contexto, la clase media aumentará, fundamentalmente en función de sus ingresos y como consecuencia de los planes para erradicar la pobreza. Esto, que en sí sería un buen dato, no traerá como consecuencia un aumento en los hábitos de consumo sostenible porque no podemos decir que el estilo de vida de la clase media sea, en sí, sustentable. Es un dato de la abundancia. Si, al mismo tiempo, 70\% de los 9.000 millones

\footnotetext{
${ }^{1}$ Cf. Visión 2050 del WBCSD (World Business Council for Sustainable Development)-Ceads (Consejo Empresarial Argentino para el Desarrollo Sostenible).
} 
vive en ciudades, urge repensar las urbes y, con espíritu innovador, la creación de nuevas ciudades. La agenda de la abundancia contrasta, pues, con la agenda de las restricciones. De 3.000 a 4.000 millones de personas vivirán próximos a cursos de agua altamente estresados. La productividad de la Tierra caerá en un promedio de 16 a 20\% y en algunos lugares en $50 \%$, lo cual quiere decir que lo que se producía antes en una hectárea entonces necesitará dos. En lo que respecta a los ecosistemas, se los valora muy poco, en especial los servicios de los que depende que haya agua potable y aire limpio. En consecuencia, sabemos que la economía y la sociedad van a crecer, pero el límite es el planeta. Se trata de desarrollarnos, pero no a cualquier costo. Esto es lo que está en tensión: la agenda de lo «insostenible» enfrentada a la agenda de «personas y planeta».

Hay ítems en los que tenemos que hacer grandes cambios: en valores, en el concepto de desarrollo humano, en el objeto de la economía, en la generación y el uso de la energía, en el ciclo de los materiales. Centrémonos en el análisis de la importancia de fijarnos un objetivo intermedio: redefinir la noción de progreso. Debemos intentar que los líderes empresariales, los gobiernos y la sociedad civil se ocupen de variables distintas al mero lucro y midan de otro modo las variables del éxito. Por ejemplo, ¿qué mide el producto bruto interno (PBI)? En realidad, mide muy pocas cosas y si bien sigue siendo de gran importancia para la toma de decisiones económicas y financieras, no lo es para definir una agenda de desarrollo. ¿Qué «no mide el $\mathrm{PBI}$ », qué factores imprescindibles para un auténtico desarrollo humano no son tomados en cuenta? Empleabilidad, seguridad, vida familiar, ecosistemas, educación, salud, nutrición, comunidad. Estos indicadores son críticos porque en la actualidad es creciente la atención a aquellos que tienen que ver más con el desarrollo que con el crecimiento. Incluso en los modernos estudios sobre la «felicidad en economía» se verifica que, después de un cierto umbral, el crecimiento del PBI no guarda relación con el aumento de felicidad o de bienestar, es decir, se desvincula de la centralidad que tiene la búsqueda del sentido de la vida para las personas. Esta redefinición del progreso y del rol de la dirigencia empresarial en la perspectiva del desarrollo humano integral y sostenible nos sumerge, así, en el universo de la RSE. 


\section{Un recorrido por las distintas escuelas de pensamiento en RSE}

Hablar de RSE implica insertarnos a la vez en un pensamiento económico-organizativo y en uno ético-filosófico. Milton Friedman, cofundador de la célebre Escuela de Chicago y Premio Nobel de Economía, sostuvo que «el verdadero deber social de la empresa es obtener las máximas utilidades (obviamente en un mercado abierto, correcto y competitivo) con el fin de producir riqueza y trabajo para todos de la manera más eficiente posible». Su mensaje fue bien claro: la única legitimación, ética y social al mismo tiempo, del actuar empresarial proviene del hecho de obtener la maximización de la utilidad en el respeto de las reglas de juego.

Hoy nadie (o muy pocos) suscribirían una afirmación tan tajante. Bien entendida, la generación de utilidades sigue siendo una condición necesaria pero no suficiente para que la empresa pueda considerarse legitimada ante los ojos de la sociedad. Esto se debe por lo menos a tres razones:

A. La responsabilidad social de la figura consumidor-ciudadano, que pasa de receptor pasivo a consumidor crítico. Esto significa que, a través de sus decisiones de compra y de sus comportamientos, el consumidor entiende que debe contribuir a construir la oferta de aquellos bienes y servicios que él demanda en el mercado. No le basta ya la sola relación calidad-precio; el consumidor-ciudadano quiere saber cómo ese determinado bien ha sido preparado y si en el curso de su producción la empresa ha violado, completamente o en parte, los derechos fundamentales de la persona que trabaja.

B. La deslocalización de las empresas. En efecto, hoy, en una época en la que los mercados de referencia de las empresas se vuelven cada vez más globales, puede suceder que producir utilidades no equivalga necesariamente a producir bienestar para todos. Debido a esto, la tradición lógica de legitimación de la empresa, según la cual la generación de las ganancias se daba ipso facto como fuente de beneficios sociales, no es más creíble. 
C. El hecho de que, a través de la RSE, la empresa entra en el ágora y se sitúa frente a la polis y no solo ante el mercado. Debido a esto, cada vez más la empresa y los empresarios tienen que ser aceptados por la sociedad civil, sea nacional o transnacional.

La RSE no es, por cierto, un elemento nuevo en las modernas economías de mercado, ya que, además de las legales, la empresa siempre tuvo obligaciones de naturaleza moral. Lo que ha ido cambiando a lo largo del tiempo es la interpretación del concepto de responsabilidad social, es decir, la especificación de aquello de lo cual la empresa tiene que sentirse responsable. La evolución de tal concepto ha tenido lugar a la par que el cambio profundo en la noción de comportamiento ético. Existe, en efecto, una pluralidad de teorías éticas, cada una de las cuales ha ejercido una gran influencia sobre la manera de definir los contenidos de la RSE (Zamagni 2004).

La posición más antigua y en un tiempo la más defendida era la propuesta por la teoría de los accionistas, según la cual la dimensión ética es externa respecto de la esfera de acción de la empresa y del actuar económico. Milton Friedman representa tal corriente de pensamiento, según lo podemos constatar al leer las afirmaciones mencionadas antes, tomadas de su libro Capitalism and Freedom: «Hay una sola responsabilidad social de la empresa: aumentar sus ganancias. El verdadero deber social de la empresa es obtener las más altas ganancias -obviamente en un mercado abierto, correcto y competitivo- con el fin de producir riqueza y trabajo para todos de la manera más eficiente posible» (1962: 133). Según esta escuela, la única legitimación ética y social del actuar de una empresa se desprende del hecho de apuntar a la maximización de las ganancias respetando las reglas del juego económico. La justificación de esta proposición reside en que, dado que la ganancia es un indicador sintético del uso eficiente de los recursos, la empresa que la maximiza hace el mejor uso posible de los recursos escasos y evita así que se desperdicien y distorsionen, con lo cual contribuye a crear, aun sin quererlo, «riqueza y trabajo para todos». En tales condiciones, valor económico y valor social 
se superponen completamente: la empresa es tanto más socialmente responsable cuanto más guía su obrar únicamente por el profit motive.

Otra teoría que sostiene y fundamenta este discurso sobre la RSE es la ética de las intenciones. Según esta, una acción es definida como moralmente buena cuando se atiene a dos reglas: la regla próxima (la conciencia) y la regla remota (la ley). El sujeto que, al conseguir armonizar la conciencia con la ley, se comporta consecuentemente cumple un acto moralmente bueno. Solo las intenciones del actor, y no las consecuencias de sus actos, son relevantes para la definición ética de un comportamiento. Es la intención, por lo tanto, lo que interesa y lo que hace beneficioso el modo en el que la riqueza es producida. Un caso de la historia estadounidense que puede ilustrar esta ética es el del gran capitalista filántropo Andrew Carnegie, autor en 1889 de The Gospel of Wealth. Carnegie se quedó desconcertado frente a las protestas de distintos sectores de la sociedad respecto a sus métodos no demasiado civilizados para conducir los negocios de su empresa: «En 1892, el St. Louis Post-Dispatch fue vocero del fuerte resentimiento de los obreros locales por las obras de beneficencia de Carnegie: con diez mil bibliotecas, este no habría podido resarcir al pueblo por los males directos e indirectos provocados por el cierre de su fábrica» (Schiera 1987: 73). El límite de la ética de las intenciones consiste en no tener en cuenta los efectos de las acciones individuales. Si mi acción, aunque inspirada por una recta intención, tiene consecuencias que repercuten negativamente sobre los demás sujetos, puede suceder que un acto moral subjetivamente lícito sea objetivamente ilícito. Por ejemplo, tomar la decisión de confiar a una entidad financiera mis rentas personales para que maximice la tasa de rentabilidad es un acto lícito según el criterio de las reglas "próximas y remotas», pero si el agente financiero invierte esas rentas de modo detestable, el acto en cuestión deviene en objetivamente ilícito.

Un intento teórico de ir más allá de los confines de la ética de las intenciones es el del «good ethic is good business»: el comportamiento ético contribuye en forma positiva al buen desempeño empresarial, lo que 
equivale a decir «la ética rinde». Esta perspectiva postula un «autointerés brilloso» por parte de los agentes económicos; ya no la maximización de las ganancias año a año sino por un largo periodo. Concretamente, esto significa que la responsabilidad social entra como argumento en la función objetiva de la empresa y ya no en el sistema de relaciones, como sucede en la teoría de los accionistas. Sin duda, se trata de un paso hacia adelante, pero demasiado corto para resultar interesante, porque si a la ética se le asigna un rol puramente instrumental -como exige el utilitarismo-, ella no estará nunca en la capacidad de incidir sobre el estado de ánimo de los actores - los sentimientos morales, en el sentido de Adam Smith- ni sobre sus comportamientos.

Otra línea de pensamiento, aún en auge, es la teoría de los stakeholders, la cual se remonta a los años 1980 y tuvo en Edward Freeman (1984) a su primer sistematizador. Grande fue el impacto de esta teoría, tanto sobre el comportamiento gerencial cuanto sobre el plano del ordenamiento institucional. ¿De qué se trata? Cada grupo de stakeholders tiene derecho a no ser tratado como un «medio orientado a cualquier fin, sino que debe participar en las determinaciones del rumbo futuro de la empresa» (Evan y Freeman 1988: 101). De esto se desprende que el fin de la empresa no es solo la maximización de la ganancia, como ocurre en la teoría de los accionistas. Por lo tanto, es tarea del directorio de la empresa realizar un balance entre los intereses de todos los stakeholders. Por ejemplo, el manager es portador de una relación fiduciaria que lo une tanto a los stakeholders cuanto a la empresa como entidad abstracta: «él está capacitado para actuar tanto según los intereses de los stakeholders, como si fuera un agente de ellos, cuanto según el interés de la empresa para garantizar su supervivencia, salvaguardando los intereses de cada grupo a largo plazo» (Evan y Freeman 1988: 104).

No es difícil encontrar el fundamento ético de esta teoría. Se trata de la ética de la responsabilidad, tal como ha sido formulada por Max Weber. La idea de fondo es que en el juicio moral, además de las intenciones, es necesario tener en cuenta el efecto de las acciones cuando estas son previ- 
sibles: las intenciones no justifican las consecuencias. Se pueden formular dos observaciones críticas a la teoría de los stakeholders. Ante todo, ella se remonta a la teoría según la cual la empresa es básicamente un «organismo» en el que conviven distintos centros de poder, cada uno dotado de un específico objetivo por alcanzar. Por ejemplo, los trabajadores desean salarios altos, condiciones de trabajo decentes y buena seguridad social; los managers querrán asegurarse sueldos altos y tratarán de acrecentar su poder y prestigio; los accionistas apuntarán a ganancias elevadas y a la expansión del capital societario. El problema es, entonces, cómo coordinar intereses múltiples, cómo hacer que los objetivos de los distintos grupos de interés sean compatibles. Por ejemplo, al manager le pagan los accionistas para que trate de satisfacer sus intereses, es decir, maximizar las ganancias; pero, al mismo tiempo, él tiene que obrar de manera tal que los intereses de todas las categorías de stakeholders sean balanceados, lo que no es sencillo. La segunda observación crítica es que, a pesar de las apariencias, la teoría de los stakeholders tiene un limitado fundamento ético. Está claro que esta teoría se apoya en la ética de la responsabilidad, pero se limita al control de los efectos previsibles derivados de una acción. Sin embargo, lo propio de la función emprendedora es generar continuamente efectos imprevisibles. En esta situación, la ética de la responsabilidad resulta insuficiente.

En este sentido, surge la pregunta acerca de si hay o no diferencias entre la RSE de la empresa de tipo «capitalista» y la de la empresa denominada de tipo «social». Básicamente, la diferencia consiste en que, por su naturaleza, la empresa social está orientada a la equidad. Este principio confiere a la RSE practicada en una empresa de tipo «social» un matiz bien preciso. En efecto, lo que caracteriza a la empresa social no es solamente la organización democrática del proceso productivo - en el caso de la cooperativa, el conocido principio de «una cabeza, un voto»- sino, fundamentalmente, el hecho de que rechaza la «lógica de los dos tiempos» en virtud de la cual primero se obtienen las ganancias (o valor agregado) y después se procede a su distribución. Es necesario subrayar la diferencia. Mientras la «mano invisible que obra 
en el mercado» para la producción de bienestar realiza sus fines más allá de las creencias y los valores de los agentes económicos, «la mano (visible) de la empresa social» que redistribuye el bienestar no puede funcionar si prescinde del compromiso afectivo de sus partes. Si estas no acogieran en su sistema de valores el principio de la equidad, el resultado no podría producirse.

El punto crucial remite a una cuestión fundamental: cómo superar la contradicción, aún tan enraizada en nuestra cultura occidental, entre «interés propio» e «interés por los demás», entre egoísmo y solidaridad. Esta contraposición errada no nos permite captar la razón de lo que constituye el «propio bien». La vida virtuosa, de hecho, es la mejor vida, no solo para los otros -como se suele creer-, sino también para uno mismo. Este es el núcleo fuerte de la ética del bien común que debería ser el auténtico fundamento ético, no únicamente de la economía en general, sino de la empresa. El bien común no se reduce a la mera sumatoria de los bienes de las distintas clases de stakeholders.

\section{E1 desarrollo humano y el enfoque de las capacidades en Amartya Sen y Martha Nussbaum}

«Redefinir el progreso» requiere profundizar en la cuestión de las necesidades humanas, a pesar de que estas no han constituido un tema central en la teoría económica del desarrollo. En efecto, la economía del siglo XX, dominada por el utilitarismo, desestimó la complejidad de las necesidades humanas y prefirió hablar de preferencias. Así, la categoría necesidades quedó relegada al patrimonio de los estudios específicos acerca de la pobreza.

La simplificación metodológica y la categoría totalizadora del homo oeconomicus encubren una antropología y una ética: al economista no le correspondería preguntarse acerca de las necesidades - cambiantes en cada contexto-, sino mirar las acciones de los agentes, las cuales revelan prefe- 
rencias personales. Por eso, el mercado se constituye en el mejor informante. En él los intercambios, en ausencia de regulaciones, son justos por definición y no hay espacio para juicios de valor: es suficiente un análisis descriptivo de lo que se observa en el mercado (Groppa 2005).

El economista indio Amartya Sen elaboró una respuesta crítica al esquema del «mundo feliz» del utilitarismo. A través de la noción de capacidades, Sen incorporó el papel de la libertad en los estudios sobre el desarrollo y en las mediciones de la pobreza. Para ello, lejos de desarrollar una lista exhaustiva de capacidades o de fijar un criterio general de evaluación, el Premio Nobel de Economía defendió la necesidad de evaluar estos asuntos en el marco de cada contexto cultural con el fin de no incurrir en nuevas formas de colonialismo. Por su lado, la filósofa norteamericana Martha Nussbaum avanzó en el esfuerzo por determinar algunas capacidades que pudieran tener un alcance intercultural y, en consecuencia, una validez normativa. Inspirada en Aristóteles y en Marx, Nussbaum enumera una serie de capacidades centrales que implican una propuesta de base para las políticas públicas. En este sentido, la noción de capacidad remite a la «vida buena» o al «florecimiento humano».

\subsection{El enfoque de las capacidades según Amartya Sen}

En lo referido a los criterios de medición de la desigualdad, Sen ha criticado no solo las concepciones bienestaristas y utilitaristas, sino también la de Rawls. Se trata, según Sen, de medir la equidad en términos de capacidades básicas y no de los recursos que las personas poseen, de la utilidad o del estado general medio de la sociedad. Sen considera, en oposición a Rawls, que la igualdad no se garantiza únicamente con la existente a nivel de derechos y de acceso a recursos.

Sen no habla de capacity sino de capability. En inglés, ambos términos significan capacidad, pero mientras el primero se refiere a la habilidad para hacer algo que de algún modo ya ha sido desarrollada o expuesta (por ejemplo, un nadador que alcanza los cien metros en vein- 
te segundos), el segundo supone más bien una habilidad aún no desarrollada ni efectivamente realizada. La primera capacidad es actual; la segunda, potencial. Concretamente, el objetivo del desarrollo humano consiste en incrementar el espacio de la libertad entendida como expansión de capacidades.

En su enfoque, Sen articula las capacidades, los funcionamientos o realizaciones y los bienes primarios. Básicamente, el primer concepto se refiere a las opciones o modos de ser y hacer al alcance de una persona, entre los cuales esta puede elegir lo que para ella tiene valor. Los funcionamientos son las realizaciones o logros elegidos por cada persona entre las n combinaciones que se le presentan. Los bienes primarios son convertidos, a través del uso, en algo valorado por la persona. Es importante señalar que ese factor de conversión depende, a su vez, de las capacidades y situaciones de las personas. En efecto, muchas veces una persona cuenta con una gran cantidad de bienes primarios (recursos), pero no tiene la capacidad de transformarlos y darles un uso que los convierta en algo valioso para su vida. Por ejemplo, la disponibilidad de transporte público no vale lo mismo para un joven que para un anciano o una persona minusválida; de igual manera, el mismo monto de ingresos no representa lo mismo para una persona enferma que para una persona sana. Una consecuencia de esto en el ámbito de la política es la prioridad de la garantía del despliegue de las capacidades de las personas frente a la mera provisión de bienes. Para Sen, solo de esta manera se asegura la libertad de las personas, objetivo central del desarrollo humano.

Como dijimos antes, si bien Sen considera que las capacidades conforman el marco respecto del cual debe predicarse la igualdad, él no desarrolla un listado de capacidades ni establece umbrales. Sin embargo, sí encontramos en sus obras numerosos ejemplos: sobrevivir o evitar una muerte prematura, comer bien y no padecer enfermedades evitables, participar en la vida comunitaria, respetarse a sí mismo, trabajar, tener libertad para elegir, ser capaz de leer y escribir, llevar una vida responsa- 
ble, ser feliz. Por otra parte, Sen reconoce al menos cinco fuentes de diferenciación de las propias capacidades: a) características personales, tales como el sexo, la edad y el estado de salud; b) el medio ambiente: contaminación, catástrofes, etc.; c) el clima social: instituciones, delincuencia, etc.; d) convenciones y costumbres sociales: discriminación, estratificación social, etc.; e) distribución de los bienes dentro de una familia. Tanto las fuentes cuanto las capacidades deben ser vinculadas a cada contexto cultural. En contraste con la noción tradicional de desarrollo económico, la perspectiva de desarrollo humano propuesta por Amartya Sen tiene como meta la libertad, es decir, el despliegue de un espectro de capacidades lo más amplio posible.

A pesar de las críticas que sostienen que las capacidades son bastante más que la libertad de elegir, Sen ha querido incluir en el debate sobre la pobreza las opciones reales y asequibles que tienen las personas con el fin de superar la mera igualdad de derechos y de oportunidades formales. Además, la relación entre las capacidades y los funcionamientos no tiene un solo sentido; por ejemplo, hay funcionamientos que generan capacidades, como ocurre cuando se cuenta con un elevado nivel de educación.

Veremos, a continuación, que Martha Nussbaum desarrolla la tarea que evitó Sen, a saber, intentar sistematizar las capacidades.

\subsection{El enfoque de las capacidades según Martha Nussbaum}

Nussbaum construye un listado de las capacidades básicas que todo ser humano debería poder desarrollar y que servirían de fundamento para las garantías constitucionales que cualquier nación del mundo debería suscribir. Ella comparte con Sen la idea según la cual la pobreza debe ser evaluada en el espacio de las capacidades y no en el de los recursos, pero sostiene que es posible reconocer algunas dimensiones sin las cuales las personas no podríamos ser quienes somos. La filósofa advierte que esta lista tiene un carácter provisorio y abierto, ya que cada cultura pone énfasis en aspectos diferentes. Nussbaum vincula estas capacidades con la 
cuestión de las virtudes en el sentido aristotélico, las cuales sirven de fundamento para una teoría del bien.

Para ello, enumera las siguientes capacidades: a) vida: garantizar su extensión normal y evitar la muerte prematura; b) salud corporal: incluye la salud reproductiva y la adecuada alimentación; c) integridad corporal: libertad de movimiento y de seguridad frente a todo tipo de agresiones; d) sentidos, imaginación y sentimientos: incluye educación, producción artística y acción religiosa; e) emociones: capacidad de desarrollo emocional sin temores; f) razón práctica: libertad de conciencia y compromiso en la planificación de la propia vida; g) afiliación: interacción social con otros, libertad de asociarse políticamente, bases sociales de respeto y capacidad de trabajo humano; h) vínculo con otras especies: dimensión ecológica de la vida humana; i) juego: capacidad de disfrutar de actividades recreativas; j) control sobre el propio entorno: capacidad de participación política y oportunidad real de ejercer la propiedad en igualdad de derechos así como acceder al empleo en iguales condiciones que los otros (Nussbaum 2002).

Nussbaum hace suya la distinción realizada por Sen entre funcionamientos y capacidades. En el caso de las políticas públicas, señala que las segundas deben constituir el horizonte de la política si no se quiere atentar contra la libertad de las personas. Pero si se trata de capacidades que son condición para el desarrollo de otras, es necesario garantizar no solo la capacidad sino el funcionamiento. Por ejemplo, ni la salud ni la enfermedad de los menores pueden quedar libradas a la voluntad de los individuos, sino que son necesarias regulaciones y códigos en materia de alimentos, medicinas y contaminación ambiental.

Habiendo revisado algunos de los principales conceptos del pensamiento de Sen y de Nussbaum, podemos preguntarnos si es preferible hablar de capacidades o de necesidades en las modernas teorías sobre el desarrollo humano. La discusión sigue abierta y dada la complejidad de los procesos podemos combinar ambos conceptos. Se podría reservar el tér- 
mino necesidades a los funcionamientos mínimos requeridos para garantizar el despliegue de las capacidades. Las necesidades serían, pues, condiciones materiales de posibilidad de las capacidades y estarían en el nivel de la conservación y reproducción de la vida humana. Una vez satisfecho dicho umbral se podría hablar de bienestar o desarrollo humano.

Es sabido que una de las críticas al enfoque de Sen lo acusa de estar demasiado centrado en el individuo y de abordar la dimensión social en términos instrumentales. En ese sentido, también Nussbaum coloca como unidad u objeto de análisis a la persona individual. Por ello, y a pesar de que en sus últimas conferencias Sen atribuye un rol importante a lo relacional y comunitario, desarrollaré más adelante el imprescindible paso, en la economía del siglo XXI, hacia las categorías de la relacionalidad y la reciprocidad.

\section{La perspectiva ética del desarrollo para lo macro, lo micro y lo «empresarial»}

De acuerdo con las corrientes de pensamiento expuestas, es preciso valorar la importancia que tiene el conocimiento científico y reflexivo sobre las necesidades y capacidades humanas. A diferencia de los enfoques más tradicionales centrados en el análisis de los ingresos o, más ampliamente, de los bienes primarios, el enfoque de las capacidades concentra su atención en un espacio de evaluación distinto, precisamente, el espacio de las capacidades, imprescindible para lograr funcionamientos valiosos. Con la noción de funcionamientos, Sen se refiere a los estados de una persona, en especial a las cosas que logra hacer o ser al vivir, en tanto que el concepto de capacidades remite a las combinaciones alternativas de funcionamientos que una persona puede lograr en su vida: capacidad de existir y actuar. La perspectiva de las capacidades se basa, entonces, en una visión de la vida humana como combinación de varios «seres y quehaceres». 
Un proceso y una estrategia de desarrollo son considerados deseables en relación con la visión particular que se tenga del sentido de la vida pensada como algo apreciable y digno de ser vivido. En el enfoque ético, la pregunta central es: «Desarrollo... ¿para qué?» Dadas la diversidad de lo que los seres humanos entienden por felicidad, la abundancia de las perspectivas culturales y las tendencias a entender estos conceptos de manera etnocéntrica, resulta complejo establecer generalizaciones en este terreno. Por ello, diversos estudiosos de la ética del desarrollo han planteado - para evitar una discusión inacabable-la conveniencia de establecer un acuerdo de nivel pragmático sobre la base de áreas específicas de coincidencia, lo cual permitiría señalar las convergencias que existen entre las diferentes culturas y perspectivas, es decir, cuáles serían los contenidos esenciales de una vida digna (Chaves 2006).

Como resultado de esos esfuerzos, se ha llegado a identificar tres valores buscados como fines, en su grado más alto, por todas las personas y sociedades; ellos pueden definir lo esencial de una «vida digna» común a todas las culturas. Esos tres valores fundamentales son el sustento de la vida, la estima y la libertad (Goulet 1995). Son fines que las investigaciones pueden mostrar como universalizables en sentido propio, aunque varíen sus modalidades específicas en diferentes épocas y lugares e incluso si luego se desagregan de diversas maneras. Denis Goulet describe el contenido de cada uno de estos valores de la siguiente manera:

A. El sustento de la vida. En todos los lugares, el valor auténtico consiste en poder mantener o enriquecer la vida. El valor reside directamente en la función vital, no en su origen ni en su escasez ni en el contenido de trabajo que puedan haberle aportado los agentes humanos. Por eso, es posible diagnosticar el subdesarrollo absoluto cuando existe escasez de bienes para mantener la vida (alimentos, medicinas, y cobijo y protección adecuados).

B. Estima. Este segundo componente de la vida digna es entendido como la percepción que tiene cada persona de ser respetada como 
un ser digno y de no poder ser utilizada por los demás como mero instrumento para conseguir sus propósitos. Todo individuo y toda sociedad buscan la estima, la identidad, el respeto, el honor y el reconocimiento. Esto no constituye únicamente una cualidad individual sino también una exigencia de colectivos; de ahí el deseo de muchas sociedades de alcanzar el desarrollo, pero también la resistencia de ciertos pueblos a las innovaciones del modelo de desarrollo que se les quiere imponer. Sin embargo, este valor conlleva el riesgo de lanzarse a la búsqueda de la abundancia y de legitimar como fin el desarrollo entendido como crecimiento, porque es el camino insustituible para ganarse el respeto. No obstante, en algunos otros casos, esta auténtica necesidad de estima se transforma en la razón por la cual algunas sociedades se resisten al desarrollo. Si la estrategia de impacto empleada por los agentes del desarrollo humilla a una comunidad, su necesidad de autorrespeto la llevará a rechazar el cambio. Por ejemplo, según la perspectiva dominante en la mayor parte de las sociedades tradicionales, una cierta imagen ideal de lo que es una sociedad buena y una vida humana que valga la pena es distinta, cuando no opuesta, a la abundancia de bienes.

C. Libertad. Aunque sometida a muy variadas interpretaciones en las sociedades desarrolladas y subdesarrolladas, en última instancia la libertad apunta siempre a la posibilidad de contar con una serie amplia de alternativas de vida así como a la posibilidad de escoger entre ellas.

La pregunta sobre para qué el desarrollo y acerca del posible acuerdo pragmático intercultural respecto de los contenidos esenciales de este objetivo no agota el proceso de análisis ético del desarrollo. La ética y la economía no tienen por qué estar divorciadas; por el contrario, deben articularse a través de procedimientos racionales y no por meros voluntarismos subjetivistas. Solo si se procede de forma coherente con la naturaleza científica de la economía y con la de la normativa de la ética, será posible aproximarse simultáneamente a los objetivos 
de eficiencia y justicia, productividad y equidad, y competitividad y solidaridad.

De acuerdo con el enfoque ético, nadie, ni siquiera un gobierno legítimamente electo, puede decidir por sí mismo en nombre de los intereses de todos. La «moralidad intrínseca» de las metas y de las medidas que se propongan para impulsar el desarrollo depende del conocimiento que se tenga de las diversas alternativas factibles con las que cuenta una acción en cada situación concreta. Asimismo, dicha moralidad intrínseca exige que las alternativas sean examinadas desde la perspectiva de su impacto potencial sobre la sociedad, los diversos grupos sociales y la «casa común» (ambiente). Se trata, por lo tanto, de decisiones tomadas ex ante, es decir, en el proceso de elaboración de la política económica, de modo tal que se puedan fijar principios de acción que representen los intereses generalizables y garanticen la consecución del bien común.

En este sentido, la incorporación de la perspectiva ética en la elaboración de un plan, una estrategia y políticas de desarrollo exige lo siguiente:

- Participación de todos los potenciales afectados por la medida concreta.

- Aporte de un análisis científico social pluralista que indique las alternativas técnicamente factibles con que se cuenta.

- Tener en cuenta el impacto sobre los diversos grupos potencialmente afectados y sobre el ambiente, según lo que los propios interesados manifiesten.

- Consideración del objetivo de identificar intereses comunes generalizables que orienten los principios de una acción concreta.

- Realización en espacios de diálogo adecuados (incluyentes, equitativos, recíprocos).

El resultado de este proceso será la base para la decisión legítima de las autoridades correspondientes respecto a las políticas por establecer. 


\section{El principio de reciprocidad: humus del enfoque de desarrollo humano y de las capacidades}

Hoy es sabido que las sociedades tienen necesidad de tres principios autónomos para poder desarrollarse de modo armónico y ser capaces de futuro: el intercambio de equivalentes (o contrato), la redistribución de la riqueza y la gratuidad-reciprocidad como práctica simbólica que refuerza el sentido de pertenencia a la comunidad. Las sociedades se desarrollan de modo armonioso si estos tres principios se mantienen activos y bien combinados. ¿Qué pasa si falta alguno de ellos? Si se elimina la gratuidad-reciprocidad, tenemos el welfare state de posguerra cuyo centro es el Estado de benevolencia: el mercado debe producir con eficiencia y el Estado debe redistribuir todo lo que el mercado produjo. Si se elimina el principio de redistribución de la riqueza, tenemos el modelo del capitalismo caritativo, en el que el mercado es asumido como la palanca del sistema libre para actuar sin impedimentos (modelo neoliberal): el mercado produce riqueza y los ricos hacen caridad con los pobres, lo cual deforma el rol de la sociedad civil. Finalmente, si eliminamos el intercambio de equivalentes, tenemos las formas extremas de colectivismo, que ignoran la lógica del contrato (Zamagni 2010).

La globalización ha extendido de modo formidable el área de aplicación del contrato y, como efecto, ha desplazado el área de redistribución-gratuidad, razón por la cual tenemos hoy sociedades más desiguales. Sin embargo, en la actualidad, una sociedad global, regional y local que no se construya sobre los tres principios señalados no puede desarrollarse adecuadamente. ¿Qué significa y qué comporta, entonces, incorporar hoy en nuestras economías el punto de vista de la reciprocidad?

Antes de esbozar una respuesta, es oportuno precisar qué es exactamente el principio de reciprocidad. Para ello, resulta útil confrontarlo con el principio de intercambio de equivalentes (de valor). Este establece que cualquier cosa que un sujeto $\mathrm{A}$ haga o dé a $\mathrm{B}$, con el cual ha decidido 
libremente entrar en una relación de intercambio, debe ser contrabalanceada a través de la respuesta de B con una cosa de igual valor. En nuestras economías de mercado, esta «cosa» se llama precio. El principio en cuestión está sujeto a dos características. En primer lugar, las determinaciones del precio de mercado preceden, en sentido lógico, a las transferencias entre A y B (si A quiere vender su casa a B, ambos deben primero ponerse de acuerdo acerca del precio y solo después podrá realizarse la transferencia del derecho de propiedad). En segundo lugar, la transferencia de $\mathrm{B}$ a A no es libre, sino que depende de lo que A dé a B; tanto que, si B se negase a cumplir, sería obligado por la fuerza de la ley. Esto equivale a decir que en el intercambio de equivalentes hay libertad ex ante desde el momento en que las partes no están obligadas a negociar, pero no hay libertad expost.

En la relación de reciprocidad, en cambio, las dos características antes mencionadas están ausentes: A se mueve libremente hacia B para ayudarlo de algún modo sobre la base de la expectativa de que B hará otro tanto, en un tiempo sucesivo, en sus relaciones mutuas o incluso en sus relaciones con $\mathrm{C}$. En la reciprocidad no solo no existe acuerdo previo sobre el precio sino que tampoco hay una obligación de reciprocidad por parte de B. El sujeto A formula solamente una expectativa; si esta es defraudada, A puede interrumpir o modificar su relación con B. Por ello, la reciprocidad es una relación intersubjetiva frágil: quien inicia la relación corre siempre el riesgo de encontrarse frente a un oportunista que se limita a recibir.

Hay otras dos diferencias entre los principios en cuestión. Por un lado, el valor de lo que B dará (o hará) a $\mathrm{A}$ o a $\mathrm{C}$ no necesariamente tiene que ser equivalente al de aquello que A dé a B. La reciprocidad, en efecto, postula la proporcionalidad y no la equivalencia: cada uno da en proporción a sus capacidades efectivas. Por otro lado, mientras que el motor principal del intercambio de equivalentes es la búsqueda de un interés (legítimo), la reciprocidad comienza siempre con un acto de 
gratuidad: A va hacia B con la actitud de quien quiere donar, no de quien desea cerrar un negocio.

La reciprocidad permite superar la obsoleta dicotomía entre la esfera de lo económico y la esfera de lo social. El utilitarismo nos dejó como herencia la idea según la cual la economía es únicamente lucro y reino de intenciones exclusivamente autointeresadas: no se es plenamente empresario si no se persigue la maximización de la utilidad. Esto llevó a identificar a la economía como el lugar de la producción y a lo social como el espacio de la distribución y de la solidaridad. Sin embargo, se puede también «hacer empresa» al perseguir, junto con el lucro, finalidades de utilidad social o al estar movidos por motivaciones prosociales. Al mismo tiempo, es necesario aclarar que, si bien un actuar económico que no incorpore la dimensión social no sería éticamente aceptable, un ámbito social únicamente redistributivo desvinculado de los recursos tampoco resultaría sostenible: para poder redistribuir hay que producir. Se debe ser eficiente para conseguir, de la mejor manera posible, el fin que libremente hemos elegido. Solo después de haber elegido el fin se puede ser eficiente para lograrlo.

La reciprocidad constituye un aporte significativo respecto de la diferencia entre competencia y competición posicional. Hablar de mercado implica siempre hablar de competencia, pero cuando esta práctica deviene competición posicional se destruye el vínculo con el otro. No hay tensión mutua en la búsqueda de un objetivo común, sino en el esfuerzo por eliminar al adversario. En un mercado abierto al principio de reciprocidad, se puede vivir el carácter social de la condición humana dentro de la vida económica. Podríamos decir que, junto con la democracia, la práctica de la reciprocidad constituye un valor fundacional de una comunidad. Dicho valor se practica en las familias, en los grupos, en las cooperativas, en las empresas y en el asociativismo. Sin el mutuo reconocimiento de una pertenencia común no hay eficiencia ni acumulación de capital que valgan. 


\section{Cultura organizativa: incorporación de las capacidades, la reciprocidad y el desarrollo humano}

Es evidente que, en la medida en que las organizaciones y los mercados son espacios humanos, en ellos no pueden estar ausentes las motivaciones que van más allá de la simple búsqueda de ganancias. Sin duda, nos encontramos frente al desafío de explorar modelos e instrumentos de gestión que contengan y expresen categorías transformadoras del business as usual. Incorporar categorías como las capacidades, la reciprocidad y el desarrollo humano dentro de la vida empresarial, económica y organizativa supone reconocer la dimensión inmaterial de la misma, así como exigir a quien tiene la responsabilidad de la buena marcha empresarial que se preocupe no solo por los resultados sino también por los procesos.

Para ello, resulta imprescindible dotar a la empresa de herramientas de análisis para poder valorar los componentes inmateriales desde una gestión multidimensional. Los aspectos por analizar son:

A. La dimensión económico-financiera: evaluar la diversidad de competencias, la mutua cooperación, el modo de fijar las remuneraciones; analizar y proyectarse globalmente según el significado etimológico de la palabra economía, a saber, hacerse cargo de la casa común que es la empresa.

B. Las redes de relaciones: reflexionar sobre el capital relacional de la empresa en cuanto a sus vinculaciones internas y externas, construir un tejido de confianza, superar las tentaciones de centralización jerárquica y tender a un policentrismo de responsabilidades.

C. Los valores, las reglas y la cultura empresarial: explicitar estos elementos a través de declaraciones de valores y códigos de ética; elaborarlos mediante procesos participativos para que sean aprehendidos por todos.

D. La dimensión socioambiental de la organización: desarrollar un clima y ambiente de trabajo adecuados y acogedores, indicadores de 
salud relacional, un sentido de pertenencia a una comunidad de trabajo, un delicado equilibrio entre el bienestar personal y el bienestar del grupo y, también, la promoción de momentos de intercambio y de conocimiento entre los trabajadores y los directivos.

E. El desarrollo del capital humano: implementar el servicio como categoría para potenciar las capacidades personales en función de un auténtico desarrollo humano; pensar en estructuras organizativas, organigramas y sistemas de decisión que favorezcan las acciones conjuntas para que todos puedan contribuir desde sus talentos.

F. El capital intelectual y la capacitación: ofrecer las mejores posibilidades para el desarrollo organizacional; apuntar a la innovación y a la ampliación del know how; valorar el conocimiento fruto de la elaboración colectiva y del trabajo interdisciplinario, cooperativo, independiente de motivaciones extrínsecas como la recompensa o la fama, conocimiento que resulte de motivaciones éticas centradas en el crecimiento colectivo y que incluyen el propio interés.

G. La comunicación interna y externa: emplear los canales formales e informales para acrecentar la comunión, la apertura a la reciprocidad genuina y la priorización de la escucha y la participación.

Esta descripción no es exhaustiva, pero ofrece las bases para que una empresa se evalúe permanentemente como un ámbito de relaciones en el que tanto sus miembros cuanto el universo de los stakeholders puedan alcanzar un auténtico desarrollo humano integral.

\section{Conclusión}

Uno de los mensajes más claros y fuertes que proviene de estos tiempos de crisis es la insuficiencia económica y ética de un individualismo que confina a la exclusión a buena parte del género humano. Para poder seguir aportando frutos, la economía de mercado tiene necesidad de un suplemento de humanidad: una refundación antropológica y ética que la transforme en un sistema al servicio de la vida de las personas y del 
planeta. Pero también se requieren otras formas de organización empresarial que, en lo interno y en lo externo, se consoliden como promotoras de relaciones, de reciprocidad y de vida digna a escala planetaria. Se requieren cambios profundos: concentrarse en la misión de la empresa sin limitarse a los resultados y considerando los modos de actuar y de relacionarse con la comunidad. De cómo abordemos la plural problemática ética de la economía, en su conjunto y en sus actores, dependerá la construcción de formas de convivencia más justas y equitativas.

\section{Referencias bibliográficas}

Chaves, Jorge Arturo

2006 Hacia un desarrollo humano integral. San José de Costa Rica: Celam.

Evan, William y Edward FreEMAN

1988 Ethical Theory and Business. Englewood Cliffs: Prentice Hall.

FreEMAN, Edward

1984 Strategic Planning: A Stakeholder Approach. Boston: Pitman.

Friedman, Milton

1962 Capitalism and Freedom. Chicago: Chicago University Press.

Goulet, Denis

1995 Development Ethics: A Guide to Theory and Practice. Washington: Rowman \& Littlefield Publishers.

Groppa, Octavio

2005 «El enfoque de las capacidades de Amartya Sen y Martha Nussbaum» En: Revista Erasmus, año VII, Nº 1, pp. 79-101.

\section{LA NACIÓN}

2013 «Hacia la metamorfosis de la empresa privada: sustentabilidad se busca». En: La Nación, Suplemento Económico, 11 de agosto, pp. 1-2. 
Nussbaum, Martha

2002 «Virtudes no relativas: un enfoque aristotélico». En: Las mijeres y el desarrollo humano. El enfoque de las capacidades. Barcelona: Herder.

SCHIERA, Pierangelo

1987 Il laboratorio Borghese. Boloña: Il Mulino.

SEN, Amartya

2000 Desarrollo y libertad. Buenos Aires: Planeta.

Zamagni, Stefano

2010 «Fraternidad, don y reciprocidad en la "Caritas in Veritate"». En:

Revista de Cultura Económica, año XXVII, N 75-76, pp.11-29.

2004 «L'ancoraggio etico dell responsabilitá sociale d'impresa». En: Actas del Convegno Internazionale Nuovi Orizzonti della Economia di Comunione, 20 de octubre. Castelgandolfo. 

ÉTICA Y PUBLICIDAD COMERCIAL 



\title{
Crítica al engaño y a la persuasión irracional en la publicidad comercial
}

\author{
Alonso Villarán \\ Universidad del Pacífico
}

En su editorial del 15 de mayo de 2013, el diario El Comercio critica en los siguientes términos la «Ley de promoción de la alimentación saludable para niños, niñas y adolescentes», ley que, entre otras cosas, regula la publicidad de alimentos y bebidas procesados dirigida a menores de edad:

La publicidad, en buena cuenta, es como una carretera por la que viaja información del vendedor al consumidor. Y lo que debería hacer el Estado con ella es crear mecanismos para que dicha información sea verdadera y no mentirosa. Por ejemplo, sancionando a las empresas que engañan u obligándolas a consignar información en sus empaques de la que claramente pueda depender la decisión de compra del consumidor (como se hace con los medicamentos que deben adjuntar una lista de posibles efectos adversos). Pero, en este caso, el Congreso ha ido más allá: prácticamente ha bloqueado la carretera impidiendo que viaje la información, tanto la mala como la buena. Y con ello, le ha quitado a las personas elementos para tomar mejores decisiones que las lleven a disfrutar más o cuidar mejor su bolsillo y, por qué no, su salud (El Comercio 2013). 
Si uno lee con cuidado el artículo 8 de la ley en cuestión notará que, como dice El Comercio, la regulación va más allá de los casos de engaño. El inciso j, por ejemplo, prohíbe «utilizar testimonios de personajes reales o ficticios conocidos o admirados por los niños y adolescentes para inducir a su consumo», lo cual no es engañar en sentido estricto, es decir, «ofrecer gato por liebre». Pero ¿basta que una pieza publicitaria no engañe para que no sea manipuladora?

Lo que El Comercio nos dice respecto de la publicidad es parcialmente cierto: la publicidad es la voz de las empresas, el medio con el que se comunican con sus clientes reales o potenciales, y su mensaje debe ser veraz. Pero la publicidad no se limita a informar, sino que muchas veces persuade, es decir, intenta convencer a la audiencia de que el producto o servicio presentado es deseable. Ahora bien, si esto es cierto, su perversión o abuso no se reduce al engaño sino que se extiende a otras formas de manipulación. Entre ellas está la persuasión irracional condenada por el artículo que nos ocupa -con la agravante de que se trata de anuncios de productos nocivos dirigidos a una población vulnerable-.

A pesar de que la publicidad no nos manipula únicamente a través del engaño, hay quienes persisten en la defensa de la publicidad comercial típica de nuestros tiempos -es decir, la que se apoya en la persuasión irracional- con argumentos tales como: «es un pilar de la sociedad de consumo», «de ella depende la industria del entretenimiento», «los adultos no son tan fácilmente manipulables». ¿Son estas defensas plausibles?

Este artículo persigue, pues, dos objetivos: distinguir, por un lado, el engaño de la persuasión irracional como formas de manipulación típicas de la publicidad comercial; y criticar, por otro lado, desde diversos frentes la publicidad comercial manipuladora en cualquiera de sus formas. Después de presentar la distinción que permite oponerse a la idea según la cual si una pieza publicitaria no es engañosa no es manipuladora, se revisan diversas críticas a la publicidad comercial manipuladora planteadas desde la moral. Este recorrido hace evidente la necesidad de una refundación de la publicidad. 


\section{Más allá del engaño: la persuasión irracional en la publicidad comercial}

En un influyente artículo sobre la publicidad comercial manipuladora, Beauchamp se refiere al «continuum de las influencias». Según este esquema, la manipulación cubre una serie de actividades controladoras que se ubican entre la coerción y la persuasión racional. La primera «ocurre si una parte deliberada y exitosamente usa la fuerza o una amenaza creíble de daño no deseado, evitable y serio, para obligar una respuesta particular de otra persona» (2000: 477). Afortunadamente -y esto no es necesariamente mérito de los publicistas- la coerción es muy poco común en la publicidad. La segunda, ubicada al otro extremo del continuum, es «un intento deliberado y exitoso hecho por una persona para motivar a otra a aceptar libremente creencias, actitudes, valores o acciones mediante apelaciones a la razón» (2000: 477). La persuasión racional presupone, pues, un buen argumento: términos claros, premisas verdaderas y ausencia de falacias. Lamentablemente, se puede afirmar que en la actualidad la persuasión racional en la publicidad comercial es tan poco común como la coerción.

La manipulación se define, entonces como: «[...] una categoría amplia que incluye todo intento exitoso de provocar una respuesta deseada de otra persona, modificando sin coaccionar las opciones disponibles para esa persona o alterando no persuasivamente [entiéndase "alterando irracionalmente'] las percepciones que otra persona tiene sobre las opciones disponibles» (Beauchamp 2000: 478).

Los ejemplos más emblemáticos de manipulación en el mundo de la publicidad son los citados antes, es decir, el engaño y la persuasión irracional.

En un artículo más reciente, Sher sostiene que una táctica de marketing -y por extensión, publicitaria- es manipuladora «si intenta motivar socavando lo que el marketero [publicista] cree es el proceso normal de toma de decisión de la audiencia, ya sea mediante (1) el engaño o (2) 
jugando con una vulnerabilidad que el marketero cree que existe en el proceso normal de toma de decisiones de su audiencia» (Sher 2011: 99).

El engaño en la publicidad es universalmente condenado: incluso la ley lo prohíbe. Pero, extrañamente, la persuasión irracional no genera el mismo rechazo a pesar de ser una forma clara de manipulación. Pareciera que hay una especie de ceguera colectiva, típica de nuestros tiempos, en relación con ella. ¿Cómo se explica si no que la ley en general no la prohíba, que la mayoría de piezas publicitarias se apoye en ella y que casi nadie se ofenda, incluso cuando se hace la publicidad de productos nocivos dirigidos a menores de edad?

La persuasión irracional en la publicidad se da principalmente en la llamada publicidad asociativa (Waide 1987). Esta consiste en vincular, con fines de lucro y sin una genuina preocupación por el bienestar de la audiencia, un bien no comercial altamente deseado por esta (la popularidad, el sexo, el poder) con un bien comercial que, en el mejor de los casos, está solo vagamente ligado al primero. Así, una cerveza promete amigos; un body spray, mujeres; un auto, poder. Esta técnica se intensifica cuando se juega con las vulnerabilidades de la audiencia, pero en ningún caso estamos frente a un engaño, pues el consumidor promedio es medianamente consciente de que el bien comercial en cuestión no garantiza el acceso al bien no comercial. A pesar de ello, la estrategia es efectiva.

«Muy bien», dirá alguien, «la persuasión irracional está muy presente en la publicidad y es una forma de manipulación distinta al engaño, pero ¿acaso es tan grave?, ¿no exageramos al condenarla?»

\section{Crítica a la manipulación en la publicidad comercial}

No exageramos. De hecho, la manipulación en la publicidad, ya sea vía engaño o como persuasión irracional, es criticada por serias razones y desde varios frentes. Dichas razones pueden agruparse en cuatro: la pu- 
blicidad manipuladora «(1) tiene consecuencias negativas para la utilidad, (2) socava la autonomía personal, (3) viola el imperativo categórico kantiano, y (4) debilita la virtud personal de sus practicantes y víctimas» (Phillips 1994: 37).

La primera crítica está enraizada en el utilitarismo clásico, escuela moral fundada por Jeremy Bentham (1748-1832) y refinada por John Stuart Mill (1806-1873), quien juzga la rectitud de los actos en función de sus consecuencias. Tal como el propio Mill afirma en su obra El utilitarismo, «el credo que acepta como fundamento de la moral la utilidad, o el principio de la mayor felicidad, mantiene que las acciones son correctas en la medida en que tienden a promover la felicidad, incorrectas en cuanto tienden a producir lo contrario a la felicidad» (Mill 1984: 49). El utilitarismo no remite al egoísmo, pues el principio utilitarista ordena promover la mayor cantidad de felicidad para la mayor cantidad de gente. En ese sentido, puede llegar a ordenar el sacrificio personal en aras de la felicidad general (aunque también, como veremos, puede ordenar el sacrificio de una minoría inocente).

Según este criterio, la manipulación en la publicidad comercial es criticada precisamente por socavar la felicidad general. Así por ejemplo, si la manipulación se produce a través del engaño, Carson (2001) considera que daña al cliente, a la competencia y a la fábrica social. Al cliente, al inducirlo a tomar decisiones de compra que de otra forma no hubiera hecho, con lo cual se afecta su economía y posiblemente su salud; a la competencia, al reducir sus ventas; a la fábrica social, al propagar la desconfianza mutua.

La segunda crítica también es consecuencialista, es decir, critica a la publicidad comercial manipuladora por sus consecuencias; pero, a diferencia de Bentham y Mill, no se enfoca en la felicidad sino en la autonomía: «Tomada como una práctica general y continua, dirigida no a individuos aislados sino a la sociedad como un todo, una publicidad que se concentra en el cultivo de deseos vía medios irracionales no cumple con 
el criterio de utilidad pues disminuye el bienestar de la sociedad al socavar los medios cognitivos para entender cuáles son nuestras verdaderas necesidades» (Santilli 1983: 29).

En otras palabras, la publicidad comercial manipuladora es mala en la medida en que nos vuelve consumidores autómatas.

A pesar de sus innegables aciertos, las críticas consecuencialistas son víctimas de al menos dos objeciones. Una de ellas proviene de los mismos defensores de la publicidad comercial manipuladora, muchos de los cuales alegan que esta tiene buenas consecuencias, especialmente económicas, pues promueve la sociedad de consumo. Esta misma defensa de la publicidad comercial manipuladora puede plantearse, de manera menos entusiasta, como lo hace Phillips:

Si la publicidad manipuladora es central a la operación del sistema, ¿con cuánta seguridad puede condenarse? Asumiendo que la condena es efectiva, la publicidad manipuladora desaparece, $\mathrm{y}$ toda publicidad se vuelve informativa, la gente gradualmente será destetada de su forma [de vida] consumista. Esto es probable que cree inestabilidad social, con una forma de gobierno más autoritaria como probable resultado final. Esto, a su vez, podría bien significar un ambiente en el que la utilidad agregada será menor a la de hoy en día (Phillips 1994: 296).

Un segundo problema apunta al utilitarismo mismo -y, en general, a todo consecuencialismo-, ya que este sería incapaz de fundar los derechos individuales:

Al preocuparse solo de la suma de las satisfacciones, puede atropellar personas individuales. Para el utilitarista, los individuos importan, pero solo en el sentido de que las preferencias de cada persona deben ser contadas junto con las de todos los demás. Pero esto implica que la lógica utilitaria, si se aplica consistentemente, puede aprobar formas de tratar a las personas que violan lo que pensamos son normas fundamentales de decencia y respeto (Sandel 2010: 37). 
Debemos, pues, ir más allá del consecuencialismo si queremos encontrar una crítica irrebatible a la publicidad comercial manipuladora.

La tercera crítica se muestra más sólida y está enraizada en la deontología kantiana. Emmanuel Kant (1724-1804) sostiene que el carácter moral de los actos no debe juzgarse en función de sus consecuencias sino de ellos mismos: hay acciones intrínsecamente buenas y acciones intrínsecamente malas. Repasemos muy brevemente su aproximación a la moral.

A diferencia de Bentham y Mill, para Kant el principio de la felicidad no puede fundar la ética al menos por dos razones: su naturaleza relativa y el ser fuente de heteronomía. Por felicidad Kant entiende la satisfacción de nuestras inclinaciones y necesidades, las que, en su opinión, varían de persona en persona e incluso en la misma persona con el transcurrir del tiempo. ¿Cómo, pues, dejarnos guiar por ella? Cuando una persona actúa motivada por la búsqueda de la felicidad, lo hace condicionada por el objeto de su deseo, heterónoma y no autónomamente.

El primer principio de la ética, del cual se derivan todos los demás, no reside en nuestra capacidad de desear, en el principio de la felicidad, sino en la razón: la ley moral o imperativo categórico. Esta ley es el principio de la moral, pues ordena incondicionalmente, a diferencia de los imperativos hipotéticos que son reglas de prudencia y siguen la forma «si quieres x, haz y». El imperativo categórico es objetivo, es decir, universal y necesario, válido en todo tiempo y en cualquier lugar. En su libro Fundamentación de la metafísica de las costumbres, este imperativo es formulado por Kant al menos de tres maneras, pero en su versión más clara ordena lo siguiente: «Obra de tal modo que uses a la humanidad, tanto en tu persona como en la persona de cualquier otro, siempre al mismo tiempo como fin y nunca simplemente como medio» (2010: 429). En otras palabras, se nos ordena tratar a las personas precisamente como personas y no como objetos. 
Por lo dicho, se sigue que, si el principio de felicidad y el imperativo categórico colisionan, debe prevalecer el segundo: ser bueno es más importante que ser feliz. Y esto, el someter nuestros deseos e inclinaciones a la ley moral, nos hace verdaderamente libres, autónomos. No garantiza la felicidad, pero nos hace merecedores de ella. Ahora bien, no basta hacer lo que la ley moral ordena, sino que la intención es crucial: la acción no solo debe ser hecha en conformidad con la ley moral sino por ella. Así, quien hace lo correcto no porque la ley moral lo ordena sino porque le conviene, no actúa moralmente, al menos no en el sentido más profundo del término.

Respecto al imperativo categórico o la deontología kantiana y la publicidad comercial manipuladora, Hare afirma:

Manipular personas [mediante la publicidad] es no tratarlas como fines en sí mismos - ciertamente no como miembros legisladores autónomos de un reino de fines...-. Pero incluso aparte de eso es algo que preferimos que no nos pase a nosotros y, en consecuencia, que no debemos desear como una máxima universal (citado en Phillips 1994: 52).

Es claro, pues, desde la perspectiva kantiana, por qué la publicidad comercial manipuladora es condenable: implica tratar a la humanidad como un mero medio de lucro y no como un fin. El empresario y el publicista que se apoyan en la manipulación para alcanzar un objetivo comercial no respetan a la audiencia: la están usando para fines comerciales. El argumento kantiano es contundente, a menos que neguemos la existencia de esta ley moral objetiva que nos ordena tratarnos como personas y no como cosas, lo cual equivaldría a negar que los seres humanos tienen dignidad y no precio.

Según lo visto, la publicidad comercial manipuladora es criticable tanto por sus consecuencias negativas cuanto, sobre todo, en sí misma: la manipulación es mala en sí misma. Hay, sin embargo, un cuarto argumento en contra de la publicidad comercial manipuladora: la crítica desde la ética de la virtud. 
De raíces platónico-aristotélicas, la ética de la virtud sostiene que la publicidad comercial manipuladora constituye una amenaza a virtudes cardinales como la templanza, fundamental a su vez para el desarrollo de otras virtudes, tales como la justicia y la prudencia. La crítica de Waide se dirige, según vimos, a la publicidad asociativa. Esta es condenable debido a que «tiende a desensibilizar a sus profesionales de la compasión, preocupación y simpatía por los otros que son centrales para la virtud moral e incentiva a su audiencia a descuidar el cultivo de las virtudes no comerciales» (Waide 1987: 75). En otros términos, la publicidad asociativa -ejemplo emblemático de la manipulación por persuasión irracionalnos hace peores personas: tanto al publicista cuanto a la audiencia.

Respecto al publicista, Waide afirma que una vida dedicada a vincular bienes comerciales con bienes no comerciales deseados naturalmente por la audiencia sin una verdadera preocupación por el bienestar de esta debe «reducir la sensibilidad de uno al motivo moral de la preocupación por el bienestar de los otros». A esto añade: «[...] la compasión, preocupación y simpatía por otros, me parece, son centrales para la virtud moral. La publicidad asociativa debe seguramente socavar esta sensibilidad en mucha de la industria de la publicidad» (Waide 1987: 75). Y es que si las virtudes o excelencia humana, como lo afirma Aristóteles (384-322 a. C.) en la Ética a Nicómaco, se adquieren mediante el hábito, los vicios también.

En el caso del daño moral provocado en la audiencia:

Cada producto contribuye con sus pocos minutos cada día, pero somos bombardeados durante horas con el mensaje de que los amigos, los amantes, la aceptación, la excitación y el poder son ganables mediante compras en el mercado, no mediante el desarrollo de las relaciones personales, las virtudes y habilidades. Nuestra energía se canaliza en carreras de manera que tengamos el suficiente dinero para ser alguien comprando la cosa adecuada en un mercado. El resultado no muy sorprendente es que descuidamos los métodos no comerciales de satisfacer nuestros deseos no comerciales. Aquellos métodos no comerciales llaman a la sabiduría, compasión, habilidad y una gran varie- 
dad de virtudes que no se pueden comprar. Parece, pues, que en la medida en que la publicidad asociativa nos anima a descuidar el cultivo no comercial de nuestras virtudes y a sustituir en su lugar bienes comerciales, nos convertimos en peores personas y, muy probablemente, menos felices (Waide 1987: 75).

La publicidad asociativa constituye una ideología que nos vende la idea de que somos lo que tenemos, lo cual sin duda empobrece nuestras vidas, es decir, el desarrollo de nuestras virtudes y nuestra verdadera felicidad.

Ahora bien, ¿la ética de la virtud es también objeto de crítica? En efecto, especialmente del esencialismo del cual depende. Así, hay quienes como Jean-Paul Sartre (1905-1980) niegan la existencia de una esencia humana, mientras que otros pensadores, como Kant, niegan que podamos conocerla. Pero, ¿estamos tan seguros de esto?

\section{Conclusión}

En este artículo se ha mostrado que los males provocados por la publicidad comercial no se limitan al engaño, sino que se extienden a la persuasión irracional. Asimismo, se ha explicado por qué la publicidad comercial manipuladora es moralmente condenable en cualquiera de sus formas.

Desde la perspectiva utilitarista, se sostiene que la publicidad comercial manipuladora promueve la infelicidad general; desde un consecuencialismo distinto, que disminuye la autonomía de la audiencia; desde la deontología kantiana, que manipular es malo en sí mismo; y desde la ética de la virtud, que nos hace peores personas. Estas perspectivas no son perfectamente compatibles y mucho menos infalibles. Sin embargo, cada una de ellas aporta argumentos sólidos en favor de una demanda moral contra la publicidad comercial manipuladora, caso que 
creemos ganado, pero cuyo veredicto final queda en manos del tribunal de la razón, del cual todos somos miembros.

Ahora bien, que el veredicto se manifieste en favor de los demandantes no debería llevar a la criminalización de la publicidad comercial y al consecuente exilio de los publicistas. La publicidad comercial, como señala ElComercio, puede ser vista como un mero instrumento, y como tal puede ser usada para bien o para mal. Pero dado que en la actualidad es utilizada sobre todo con fines manipuladores, debe ser refundada.

La creatividad que caracteriza a los publicistas debe conducirlos a reinventar la publicidad comercial. Compete también a los empresarios que los contratan no solo tolerar sino exigir este cambio.

\section{Referencias bibliográficas}

ARISTÓTELES

2010 Ética a Nicómaco, trad. de Julio Pallí Bonet. Madrid: Editorial Gredos.

Beauchamp, Tom

2000 «Manipulative Advertising». En: Bowie, Norman E. y Tom L. Beauchamp (eds.), Ethical Theory and Business. New Jersey: Prentice Hall, pp. 476-485.

BENTHAM, Jeremy

2012 The Principles of Morals and Legislation, ed. de Robert M. Baird y Stuart E. Rosenbaum. Nueva York: Prometheus Books.

CARson, Thomas

2001 «Ethical Issues in Selling and Advertising». En: The Blackwell Guide to Business Ethics, ed. de Norman E. Bowie. Oxford: Blackwell Publishing, pp. 186-205. 
EL COMERCIO

2013 «[Editorial]. Una ley poco saludable». En: El Comercio, 15 de mayo. <http://elcomercio.pe/politica/opinion/editorial-ley-poco-saludable-noticia-1576731>.

KANT, Immanuel

2010 Fundamentación de la metafísica de las costumbres, trad. de Roberto Aramayo. Madrid: Editorial Gredos.

MiLL, John Stuart

1984 El utilitarismo, trad. de Esperanza Guisán. Madrid: Alianza Editorial.

Phillips, Michael

1994 «The Inconclusive Ethical Case against Manipulative Advertising». En: Business and Professional Ethics Journal, año 13, N 4, pp. 31-64.

SANDEL, Michael

2010 Justice: What's the Right Thing to do? Nueva York: Farrar, Straus and Giroux.

SANTILLI, Paul

1983 «The Informative and Persuasive Functions of Advertising: A Moral Appraisal». En: Journal of Business Ethics, año 2, $\mathrm{N}^{\circ} 1$, pp. 27-33.

SHER, Shlomo

2011 «A Framework for Assessing Immorally Manipulative Marketing Tactics». En: Journal of Business Ethics, vol. 102, N 1, pp. 97-118.

WAIDE, John

1987 «The Making of Self and World in Advertising». En: Journal of Business Ethics, vol. 6, $\mathrm{N}^{\circ}$ 2, pp. 73-79. 


\title{
La autorregulación en la publicidad comercial ${ }^{1}$
}

\author{
Rodolfo León \\ Asociación Nacional de Anunciantes
}

\section{La autorregulación en la publicidad}

Si la ética es definida como el conjunto de normas que deben regir la conducta humana, cabe preguntarnos sobre el carácter ético de las acciones propias de la publicidad, en tanto están encaminadas a influenciarnos como personas y como sociedad. De hecho, estamos expuestos a su influencia a través de todos los medios de comunicación. En un principio fueron los impresos, luego la radio y la televisión, a ellos se suma ahora el internet. Incluso llegamos a asimilar colectivamente frases, expresiones e imágenes que nos llegan a través de los spots comerciales: estos elementos publicitarios definen formas y actitudes en nuestras vidas y en la de las comunidades donde nos desenvolvemos. Esta realidad es tan palpable que, años atrás, Bill Bernbach, fundador de la agencia DDB, sostuvo que

\footnotetext{
${ }^{1}$ Este artículo está basado en otros que he escrito en los más de diez años que llevo desempeñándome en el ámbito de la publicidad; además incluye aportes de otros profesionales que generosamente han colaborado con la Asociación Nacional de Anunciantes (ANDA) en este esfuerzo común por impulsar las mejores prácticas en la comunicación comercial. Confío en que sepan ellos disculparme si encuentran sus palabras en este escrito sin haberles dado el crédito que merecen individualmente.
} 
«todos los que utilizamos los medios de comunicación masiva damos forma a la sociedad: podemos hacer vulgar esa sociedad, embrutecerla o ayudarla a elevarse a un nivel superion».

Esta dimensión ética es aún más importante en la actualidad, ya que constatamos las crecientes exigencias a las empresas respecto de la responsabilidad social corporativa, es decir, respecto de la contribución que una empresa hace a la sociedad en la que se desenvuelve. Un estudio de la firma estadounidense Edelman, especializada en temas de imagen corporativa y de marcas, reveló ya hace algunos años que el principal elemento que conforma esa imagen de responsabilidad social en una corporación es su conducta ética. En efecto, dicha conducta puede motivar decisiones de compra por parte del consumidor que lo llevan a favorecer los productos de empresas percibidas como éticas. Además, el evidente y creciente poder del consumidor en las redes sociales hace cada vez más importante portarse éticamente a los ojos del público para seguir gozando de su preferencia.

Desde la naturaleza de servicio público propia de la radiodifusión hasta la interacción que las agencias de publicidad y los anunciantes tienen con el público a través de la publicidad, las actividades de la industria de la comunicación comercial (conformada por medios, agencias y anunciantes) constituyen un tema social y jurídico sensible. Por ejemplo, las conductas aisladas que desmerecen el servicio que la industria debe rendir al mercado afectan al conjunto de la misma y erosionan su imagen. Estas conductas provocan respuestas por parte de los poderes públicos que tienen efectos restrictivos de alcance general y que, por ello, suelen perjudicar a aquellas empresas cuya comunicación comercial, responsable y veraz sí se ajusta a los marcos éticos y legales.

Un sistema de autorregulación es la respuesta de la propia industria a la inquietud social referida a la exigencia de garantías de confianza y credibilidad en la publicidad. Las empresas, solas o asociadas como industria, deciden autorregularse para mantener las condiciones que permi- 
tan su sostenibilidad y adecuarse, así, a las demandas cambiantes de su entorno, del cual son parte como ciudadanos corporativos y como ciudadanos privados. Su objetivo es contribuir a que la publicidad constituya un instrumento útil en el proceso económico, así como velar por los derechos de los consumidores y usuarios y por la lealtad en la competencia. En un claro acto de responsabilidad, los anunciantes hemos insistido, además, en la necesidad de que el contenido de los programas de televisión guarde coherencia con los estándares éticos de nuestros anuncios comerciales, ya que dichos programas son el vehículo desde el cual se difunde la publicidad.

La intención de la autorregulación es moderar el ímpetu con que los anunciantes persiguen sus fines para mantenerlos dentro de límites no destructivos; pero sin eliminar dicho ímpetu, porque se perdería la energía necesaria para seguir creciendo. De no moderarlo, la credibilidad, el prestigio y aun la licencia social para operar de estos anunciantes se pierden y quedan expuestos a protestas sociales o a medidas regulatorias excesivas por parte de las autoridades, medidas que son perjudiciales para los resultados del negocio. En ausencia de una autorregulación eficaz se crea un espacio para la regulación estatal, con lo cual se promueve la actividad punitiva del Estado con todos sus resortes, bendiciones y perdiciones. Tenemos que meditar, pues, detenidamente sobre los efectos restrictivos que tendría una participación reguladora por parte del Estado si es que los empresarios no nos adelantamos asumiendo un papel autorregulador efectivo. En principio, algunos efectos negativos inmediatos de la intervención reguladora estatal son la pérdida de la autonomía y el aumento de los costos de transacción debido a que la administración pública siempre actúa de manera formal y, por ello, sus procesos suelen ser lentos.

Gracias a la autorregulación, las propias empresas asumen voluntariamente el compromiso de garantizar a la sociedad el rigor ético de las comunicaciones comerciales a través del establecimiento de normas éticas y del desarrollo de mecanismos que permitan solucionar even- 
tuales controversias. En este contexto, lejos de pretender ser un sustituto del control legal, la autorregulación sirve como su complemento. En efecto, por medio de la autorregulación, los consumidores pueden beneficiarse de una mayor protección respecto del contenido de los programas y de los anuncios publicitarios; asimismo, las empresas encuentran un cauce ágil y eficaz para prevenir y dirimir las controversias que pudieran aparecer.

La autorregulación se construye sobre dos elementos, pilares propios de todo sistema de autodisciplina, a saber: la producción de reglas de conducta que figuran por escrito en un código de ética y su aplicación por medio de un órgano de control deontológico independiente, un consejo de autorregulación. Por un lado, el marco legal para la actividad publicitaria está dado por el «Código de defensa del consumidor» y por la «Ley de represión de la competencia desleal», cuyo cumplimiento es vigilado por el Instituto Nacional de Defensa de la Competencia y de la Protección de la Propiedad Intelectual (Indecopi); y por el propio sistema judicial. Por otro lado, se cuenta con el «Código de ética publicitaria del Perú» y con el Consejo Nacional de Autorregulación Publicitaria (Conar), en el que anunciantes, agencias de publicidad y medios participan para mantener las buenas prácticas publicitarias. En este sentido, es imprescindible que los actores, es decir, anunciantes, publicistas y medios, asumamos el reto de establecer un sistema de autorregulación eficaz para la industria de la comunicación comercial que permita mantener la independencia y la iniciativa en la realización de nuestras actividades comerciales. Esta es la única manera de conseguir este objetivo y de evitar, así, la bienintencionada pero necesariamente restrictiva injerencia reguladora del Estado.

Entre las diversas razones, incluso económicas, para poner especial cuidado en el desarrollo de una publicidad ética, la Cámara de Comercio Internacional señala y organiza las que se presentan en el cuadro 1. 
Cuadro 1. Publicidad ética: impactos, prácticas y consecuencias

\begin{tabular}{|l|l|l|}
\hline \multicolumn{1}{|c|}{$\begin{array}{c}\text { A quién, qué y } \\
\text { cómo impacta }\end{array}$} & \multicolumn{1}{|c|}{$\begin{array}{c}\text { Consecuencias de la } \\
\text { práctica ética }\end{array}$} & $\begin{array}{l}\text { Consecuencias de la } \\
\text { práctica no ética }\end{array}$ \\
\hline $\begin{array}{l}\text { Confianza del } \\
\text { consumidor. }\end{array}$ & $\begin{array}{l}\text { Aumento de la satisfacción } \\
\text { del cliente o consumidor. }\end{array}$ & $\begin{array}{l}\text { Insatisfacción del } \\
\text { cliente o consumidor. }\end{array}$ \\
\hline Valor de la marca. & $\begin{array}{l}\text { Incremento del valor de la } \\
\text { marca. }\end{array}$ & $\begin{array}{l}\text { Maltrato del valor de } \\
\text { la marca y daño eco- } \\
\text { nómico a la empresa. }\end{array}$ \\
\hline $\begin{array}{l}\text { Credibilidad de la } \\
\text { industria. }\end{array}$ & $\begin{array}{l}\text { Mejora de la reputación de } \\
\text { la industria. }\end{array}$ & $\begin{array}{l}\text { Daño a la reputación } \\
\text { de la industria. }\end{array}$ \\
\hline $\begin{array}{l}\text { Efectividad de la } \\
\text { publicidad y las } \\
\text { comunicaciones. }\end{array}$ & $\begin{array}{l}\text { Conservación de la efectivi- } \\
\text { dad de la publicidad y la } \\
\text { comunicación. }\end{array}$ & $\begin{array}{l}\text { Reducción de la efecti- } \\
\text { vidad de la publicidad } \\
\text { y la comunicación. }\end{array}$ \\
\hline $\begin{array}{l}\text { Libertad para la } \\
\text { publicidad y la } \\
\text { comunicación. }\end{array}$ & $\begin{array}{l}\text { Reducción del riesgo de que } \\
\text { las leyes y regulaciones res- } \\
\text { trinjan las actividades de } \\
\text { publicidad y comunicación. }\end{array}$ & $\begin{array}{l}\text { Restricciones y regula- } \\
\text { ciones burocráticas del } \\
\text { gobierno. }\end{array}$ \\
\hline Carrera personal. & $\begin{array}{l}\text { Protección de la reputación } \\
\text { profesional. }\end{array}$ & $\begin{array}{l}\text { Daño al futuro de la } \\
\text { carrera. }\end{array}$ \\
\hline
\end{tabular}

Es claro, pues, que la publicidad deberá estar en armonía con el interés social y el desarrollo nacional para promover, en la medida de lo posible, la educación y la cultura. Es necesario tomar en cuenta, para ello, que el contenido de un mensaje publicitario comprende tanto lo que se dice cuanto la forma en que se presenta.

\section{Códigos de ética publicitaria}

En términos generales, los códigos de ética publicitaria apuntan a que la publicidad no utilice procedimientos engañosos que exploten la credulidad o la ignorancia del consumidor o usuario respecto de las ca- 
racterísticas, cualidades, usos o funciones del bien o servicio ofrecido. Se trata de no crear en el consumidor falsas o desproporcionadas expectativas de satisfacción. En este sentido, el «Código de ética publicitaria» del Conar ${ }^{2}$ establece cuatro principios: legalidad, leal competencia, veracidad y decencia; cuyo contenido y aplicación podemos desglosar como sigue:

A. Veracidad: cualquier información sobre un determinado bien o servicio debe coincidir con la realidad del mismo; se deben evitar los mensajes que, por acción u omisión, engañen al consumidor, lo induzcan a error o simplemente no le permitan tener una concepción clara y justa del valor de lo que se le está ofreciendo.

B. Verificabilidad: el consumidor, el usuario y el público en general deben tener la posibilidad de solicitar la comprobación de la veracidad de las aseveraciones sobre las cualidades y/o condiciones de un determinado bien o servicio contenidas en un mensaje publicitario.

C. Respeto: todo mensaje publicitario debe respetar la dignidad de la condición humana, así como los valores sociales y nacionales, con especial consideración hacia la familia; debe presentar valores positivos de conducta humana; se abstiene de utilizar representaciones o palabras ofensivas o que atenten contra la moral, las buenas costumbres y el orden público; evita mostrar como valiosas conductas groseras, obscenas, repulsivas, antisociales o delincuenciales.

D. Ausencia de ofensas: los mensajes publicitarios deben ser contrarios a cualquier tipo de ofensa, menosprecio o discriminación por razones de raza, sexo, condición social, religión, nivel cultural, situación económica o defecto físico.

E. Corrección en el uso del lenguaje: lo cual no impide el uso de modismos y giros populares cuando los personajes o situaciones lo requieran.

F. Respeto a la ley: todo mensaje publicitario debe sujetarse al ordenamiento jurídico de la Nación.

G. Reconocimiento: el público debe poder distinguir un mensaje publicitario con toda claridad.

${ }^{2}$ Cf. < http://conarperu.org/web/codigos-/codigo-de-etica.html>. 
H. Lealtad en la competencia comercial: al promover las características de un producto y/o servicio o difundir su imagen, lo mismo que la de una institución o una situación determinada, ningún mensaje publicitario debe hacer referencias específicas a bienes, servicios y/o instituciones ajenos a fin de desacreditarlos o denigrarlos; no debe tampoco presentar manifestaciones que creen confusión con bienes, servicios o instituciones ajenos.

I. Carácter original del anunciante: ningún anunciante debe imitar o copiar, en todo o en parte, manifestaciones publicitarias de otros anunciantes.

J. Honorabilidad: ningún mensaje publicitario debe presentar la figura humana, en especial la de la mujer y el niño, en situaciones indecorosas, deshonestas, inmorales o de dudosa moralidad. Tampoco los debe presentar en circunstancias peligrosas o potencialmente peligrosas.

K. Consideración: no se debe inducir a los niños a juzgar a sus mayores en función de la acogida que estos hayan dado o no a las sugerencias de un mensaje publicitario.

\section{La decencia y el buen gusto}

Lo que antecede es un enfoque técnico o académico que podría ser complementado con un test de buen gusto. A pesar del carácter subjetivo de este, el sentido común desarrollado en una sociedad asume ciertas normas no escritas que establecen el límite entre lo que podemos o no considerar como decente y como correspondiente al buen gusto. En este sentido, hay cinco preguntas que todos podemos hacernos para determinar si lo que estamos contemplando o planeando es de buen gusto:

A. Intención: ¿Cuál es la intención real del material presentado? ¿Es ganar un premio o contribuir de alguna manera constructiva? ¿O es simplemente atraer la atención (rating) a través del shock o el escándalo, que apelan a tendencias negativas del ser humano?

B. Relevancia: ¿El material presentado es de verdadero interés y tiene valor? ¿Guarda relación con su contexto? ¿Es realmente de interés para el público? 
C. Contexto: ¿Dónde y cuándo aparece el mensaje? ¿Quiénes son más sensibles a verlo y oírlo? Esto es importante porque, por ejemplo, ciertos temas pueden ser apropiados a las diez de la noche, pero no a las cinco de la tarde.

D. Ingenio: ¿Cómo se presenta la historia o el material? ¿Hay elegancia o vulgaridad y crudeza? Por ejemplo, cuando alguien cuenta un chiste sucio que no es gracioso, sino solamente crudo, uno no se siente cómodo y hasta siente vergüenza ajena por quien lo está contando. Pero si el mismo contenido forma parte de un chiste que está muy bien construido y excelentemente narrado, uno se sitúa ante él de otra manera.

E. Orgullo: ¿Se sentiría orgulloso de que su nombre fuera asociado con el material presentado? ¿Estaría orgulloso de colocar su firma en él? ¿Su hija adolescente se sentiría orgullosa de usted por haber hecho ese trabajo? ¿Se siente usted cómodo viéndolo u oyéndolo en compañía de sus hijos pequeños o jóvenes?

Aunque los criterios para definir el gusto y la decencia no pueden ser impuestos y cambian en cada contexto histórico-social, debemos esmerarnos siempre en crear comerciales y presentar contenidos que contribuyan con el enriquecimiento y la comprensión de lo humano.

\section{El valor de la publicidad ${ }^{2}$}

Los anunciantes sostenemos que la publicidad es valiosa para la sociedad porque:

- Incrementa el valor que reciben los consumidores. Al ayudar a las compañías a diferenciarse unas de otras, estimula la competencia, disminuye los precios e incrementa la calidad.

${ }^{3}$ Cf. <www.valueofadvertising.org $>$. 
- Promueve la elección del consumidor. La publicidad permite a las compañías informar acerca de los diferentes productos que ofrecen en respuesta a los diversos gustos y necesidades; por ello, ayuda al consumidor a ejercer su derecho a elegir.

- Impulsa el crecimiento económico. La publicidad desempeña un rol clave en una economía dinámica porque conduce a las compañías hacia el éxito; existe un vínculo irrefutable entre los índices de inversión en publicidad y el crecimiento del PBI de los principales mercados.

- Crea puestos de trabajo. A través de su efecto positivo en el crecimiento, la publicidad ayuda a generar empleo; además, como industria constituye en sí misma un enorme empleador.

- Es el alma de los medios de comunicación. La publicidad financia a un conjunto diverso y plural de medios; sin ella, muchos no existirían, incluido gran parte del contenido de internet.

- Financia los deportes y la cultura. La publicidad y el auspicio desempeñan un rol esencial en la realización de eventos como los Juegos Olímpicos y la Copa Mundial de la Federación Internacional de Fútbol Asociado (FIFA).

Hasta aquí podríamos sentirnos satisfechos con la claridad de los conceptos que rigen nuestra actividad, así como con el aporte estético, emocional y material que dicha actividad implica para la sociedad y para la economía. Sin embargo, hay desafíos y tareas pendientes.

\section{El desafío}

A pesar de lo expuesto con respecto a los códigos y principios éticos, en la práctica nos encontramos con una percepción negativa de la publicidad por parte del público. Esta percepción encuentra su expresión más extrema en la página 111 del documento «La gran transformación, Comisión de Plan de Gobierno 2011-2016. Gana Perú», donde se señala: 
La publicidad que hoy se difunde en los medios de comunicación es engañosa y falsa; conlleva una estafa grosera a los consumidores que, de buena fe y creyendo en la institucionalidad del mercado, le prestan algún crédito [...]. Asimismo, la autorregulación, promovida entusiastamente por los agentes económicos, y avalada por el propio Indecopi, es en realidad una patente de corso para la impunidad y la vulneración de los derechos de los consumidores.

Estas líneas denotan una intención intervencionista que desmerece el servicio que la industria ofrece al mercado, afecta al conjunto de la misma y erosiona su imagen. Los casos a los que se alude en el texto favorecen la percepción negativa de la publicidad por parte del público. También apoya la inevitable asociación que las personas hacen entre la publicidad y el contenido de los medios desde los cuales se difunde.

Indudablemente, la industria publicitaria tiene que responder con altura a estos cuestionamientos, así como evitar potenciales excesos regulatorios. Pero eso comienza por eliminar los casos que sirven de apoyo a las críticas. El problema de fondo no consiste en que no se conozcan los principios que rigen la actividad publicitaria y la de los medios. De hecho, los anunciantes y publicistas saben que la publicidad debe ser legal, veraz, leal y decente; los medios, a su vez, conocen los principios que deben regir su actividad: veracidad, imparcialidad, uso de un lenguaje correcto, tratamiento cuidadoso del sexo y de la violencia, cuidado de los menores, decencia y buen gusto. Pero los códigos de ética no pueden ser impuestos; tienen que ser el reflejo de un conjunto de principios y valores que los actores asumen con convicción en su práctica diaria: la publicidad ética comienza con personas éticas. El código de ética tiene que ser un documento vivo y apoyado por la decisión política de cumplirlo y hacerlo cumplir. 


\section{La tarea}

¿Qué nos toca hacer sostenidamente para desarrollar esta conciencia ética en los profesionales que componen la cadena de la comunicación comercial? Creemos que hay un rol que corresponde en particular a los diferentes grupos de profesionales relacionados a ella:

- Los académicos deben formar personas éticas que rijan su vida personal y profesional por un conjunto de principios y valores sólidos.

- Los publicistas deben crear mensajes publicitarios que, además de ajustarse a los principios éticos, sean inclusivos, es decir, capaces de rechazar los estereotipos de raza, origen y género.

- Los medios deben producir y emitir principalmente programas con contenidos que respeten la decencia y el buen gusto de la sociedad.

- Los anunciantes deben velar por que exista coherencia ética entre su publicidad y los contenidos de los medios desde los cuales se difunde. 

ÉTICA, MINERÍA Y AMBIENTE 



\title{
Una propuesta para el análisis de conflictos sociales en términos de deliberación, agencia y reconocimiento. El caso de la minería en el Perú ${ }^{1}$
}

\author{
Gianfranco Casuso \\ Pontificia Universidad Católica del Perú
}

\section{La realidad del conflicto minero: contradicción entre crecimiento e insatisfacción}

Desde comienzos del año 2000, debido a una creciente oposición popular frente a las actividades extractivas, fueron implementados en el Perú mecanismos que permitirían incrementar el margen de transferencias fiscales por concepto de extracción minera, en la lógica de que ello debería mejorar los estándares de vida de la población y convencerla de los beneficios de la minería.

\footnotetext{
${ }^{1}$ Los resultados presentados en este artículo forman parte de una investigación financiada por el Vicerrectorado de Investigación de la Pontificia Universidad Católica del Perú. Quiero agradecer a Pepi Patrón, quien dirige el equipo en el que se enmarca este trabajo, y a Hernán Aliaga, por su valiosa colaboración en la recolección y sistematización de los datos empíricos.
} 


\section{Gianfranco Casuso}

La primera innovación llegó el año 2001 con la aprobación de la Ley 27506, por la cual se incrementaban de 20 a 50\% las transferencias del gobierno nacional a los subnacionales por concepto de canon minero. Luego numerosos ajustes dirigidos a mejorar la asignación a cada gobierno subnacional devinieron en una reforma que fue inicialmente suscrita en julio de 2004 (Ley 28332). Hacia esta fecha se dio una situación excepcional respecto al precio de los commodities mineros a nivel internacional, lo que permitió que desde ese año hasta 2007 las transferencias aumentaran trece veces, es decir, de 90 millones a más de 1.000 millones de dólares.

Debido al alto nivel de ingresos de las empresas mineras y luego de que diferentes actores demandaran una revisión de los contratos de estabilidad tributaria y exoneración del pago de regalías, firmados en la década de 1990 con numerosas empresas, el entonces presidente Alan García llevó a cabo, en diciembre de 2006, lo que sería la segunda innovación institucional: el Programa Minero de Solidaridad con el Pueblo, mejor conocido como «óbolo minero», a través del cual se eximía a las empresas del pago de impuestos a las sobreganancias a cambio del compromiso de invertir en proyectos de desarrollo social en las regiones mineras.

A pesar de todo ello, de acuerdo a un reporte de la Defensoría del Pueblo (2009), el número de conflictos sociales desde febrero de 2004 hasta diciembre de 2008 tuvo un crecimiento histórico, pasando de 47 a 197 -y llegando a la cifra de 220, entre conflictos activos y latentes, en octubre de 2013 (Defensoría del Pueblo 2013) -. Lejos de verse amainados, los conflictos aumentaron en cantidad e intensidad, siendo lo más desconcertante el hecho de que se concentraran precisamente en aquellas zonas que percibían canon minero o en jurisdicciones aledañas a zonas de explotación minera (como sucedió en Áncash o Cajamarca). Los rediseños institucionales no consiguieron mejorar los indicadores de bienestar social y económico en las regiones mineras y más bien parecen ser -paradójicamente-los principales causantes de la escalada de conflictos. 

agencia y reconocimiento. El caso de la minería en el Perú

Para algunos especialistas, como Javier Arellano Yanguas, la razón fundamental de esto último es la creación de una estructura de incentivos por rentas mineras que propiciaría el incremento cuantitativo de la conflictividad ${ }^{2}$. En tal sentido, Arellano distingue tres tipos de conflictos, de los cuales dos responden a la estructura de incentivos existente a partir de las innovaciones institucionales de 2004 y 2006:

A. Conflictos que instrumentalizan la protesta para negociar una mejor redistribución de la renta. En estos, cuanto más exitosos son los actores locales en «aparentar» que su movilización conlleva una oposición radical a la minería, más fuerte es su posición negociadora con la empresa ${ }^{3}$.

B. Conflictos que emplean la protesta buscando una redistribución más favorable de la renta entre los distintos niveles de gobierno y la población. Este tipo se subdividiría a su vez en: i) conflictos entre población y autoridades locales por ineficiencia en el manejo del canon; ii) conflictos entre niveles de gobierno en torno a las reglas para la distribución de las transferencias del canon minero y otras transferencias fiscales; y iii) conflictos entre límites fronterizos de jurisdicciones vecinas y eventuales beneficiarias del canon.

C. Finalmente, el tipo de conflicto más emblemático sería aquel que supone una genuina oposición a la minería, frecuentemente relacionada con la potencial afectación a los medios de vida de los involucrados.

\footnotetext{
${ }^{2}$ «Esas innovaciones ni abordaron la incapacidad del Estado de promover con eficacia el interés colectivo ni contribuyeron a reforzar su legitimidad en las zonas rurales del país. En cambio, crearon incentivos para que distintos actores en las regiones mineras recurrieran a los conflictos para maximizar las ventajas que pudieran obtener de esos nuevos mecanismos de redistribución» (Arellano Yanguas 2013: 155).

${ }^{3}$ «Las poblaciones locales con frecuencia enmarcaban sus demandas en discursos sobre daños ecológicos y los perjuicios que la minería les suponía para sus medios de subsistencia. Sin embargo, las negociaciones se solían centrar en oportunidades de empleo, compensación económica, promoción de pequeñas empresas locales e implementación de proyectos de desarrollo social» (Arellano Yanguas 2013: 168).
} 
A la par del incremento cuantitativo de los conflictos, la estructura de incentivos ejerce también una significativa transformación cualitativa de los móviles de la protesta, redirigidos hacia la búsqueda de beneficios inmediatos, en lugar de hacia cambios en las leyes, en las prácticas de gobierno (Arellano Yanguas 2011: 182) o, incluso, en las estructuras y categorías sociales. De esta manera, el potencial constructivo del conflicto social se minimiza estratégicamente y se obtura y distorsiona en la misma proporción en que los involucrados minimizan, obturan y distorsionan sus demandas, traducidas ahora a estrictos reclamos monetarios ${ }^{4}$.

En suma: aunque los datos macroeconómicos nos hablan de crecimiento y de un mayor bienestar social, en el desagregado por regiones no

\footnotetext{
${ }^{4}$ No solo ello, aunque el factor «canon minero» es el principal elemento distorsionador $\mathrm{y}$, en buena medida, encubridor del carácter multidimensional que originalmente alberga toda demanda, la implementación del «óbolo minero» (por lo demás, ilustrativa de una dinámica extendida de transferencia de responsabilidades desde el Estado hacia los actores privados) contribuyó a generar una comprensión anómala acerca de las responsabilidades que le corresponden al gobierno central. En la práctica, esta política conllevó que las empresas se convirtieran en el principal foco de la ira y de las demandas populares, lo cual erosionó la legitimidad del Estado al reafirmar la convicción de que este ni era un mediador imparcial, ni tenía presencia en las zonas más remotas del país a menos que se necesitaran imponer los intereses de la élite económica, con frecuencia a través del empleo de la violencia (Arellano Yanguas 2013: 162).

Al respecto, Arellano comenta un estudio sobre el tema, elaborado por Goldberg y colaboradores y publicado en 2008, que analiza una base de datos de los distintos estados de Estados Unidos para el periodo 1929-2002, en el que se concluye que la dependencia de las industrias extractivas condujo a un menor crecimiento económico y a un débil desarrollo social. En el caso específico de Louisiana y Texas se descubrió que la causa principal fue la utilización de las rentas por parte de las autoridades políticas para el mantenimiento de una presión fiscal baja y para la obtención de apoyo poblacional a través de estrategias clientelistas, aumentando así sus posibilidades de permanencia en el poder, reduciendo la oposición política y afectando la calidad de las políticas públicas. Caselli y Michaels tienen conclusiones semejantes para el caso de municipios brasileños, y señalan la corrupción como la causa más probable (Arellano Yanguas 2011: 190).
} 
Una propuesta para el análisis de conflictos sociales en términos de deliberación, agencia y reconocimiento. El caso de la minería en el Perú

se encuentra evidencia alguna de que la actividad minera o el canon hayan afectado positivamente el bienestar social global y el desarrollo en las zonas mineras 5 .

Esta información es consistente con las percepciones de insatisfacción que recoge el Latinobarómetro (1995-2011), así como con los resultados que arroja la Encuesta Nacional de Hogares (Enaho) durante el periodo analizado. Por ejemplo, la satisfacción con respecto al funcionamiento de la democracia en Áncash y Tacna, dos de las regiones que mayor cantidad de transferencias fiscales por minería han recibido, pasa de un nivel de insatisfacción total («nada satisfecho») de 10,7\% y $6,7 \%$ en 2006 , a 20,0\% y 26,7\% en 2010, respectivamente. Del mismo modo, la garantía de tener oportunidades de empleo pasa de una percepción de «Nada garantizadas» en 2007 con 38,5\% y 46,7\%, a 35,0\% y 53,3\%, en 2009 , respectivamente para los mismos departamentos. La percepción sobre el grado de satisfacción con la vida pasa de «Muy satisfecho» en 2006 , con $16,7 \%$ y $13,3 \%$, a $11,1 \%$ y $0,0 \%$ en 2010 , también respectivamente. Otro dato de la Enaho señala que la percepción de que el país está gobernado solo para el beneficio de ciertos grupos poderosos pasa de

\footnotetext{
${ }^{5}$ Para tal fin, Arellano verifica a nivel regional seis indicadores de cambios anuales: tasa anual de crecimiento del PBI regional, excluyendo actividades mineras; variación anual de la pobreza; variación anual en el porcentaje de la población con acceso a agua potable; variación anual en el porcentaje de población con servicios de saneamiento en sus hogares; variación anual en la tasa de asistencia escolar de los niños entre tres y cinco años; y variación anual en la tasa de asistencia escolar de los niños entre doce y dieciséis años. Estos indicadores son combinados con otras variables en un modelo de regresión de panel de efectos aleatorios (verificables en Arellano Yanguas 2011: 198-201). De todo ello, el autor concluye que la minería en términos generales y las transferencias de canon en particular han tenido un impacto ínfimo sobre las poblaciones aledañas a las operaciones mineras (la mejora de la asistencia escolar sería el único indicador sobre el que el canon minero parece tener un efecto positivo). El análisis a escala local concluye en el mismo sentido: «los municipios que recibieron mayores transferencias de canon entre 2001 y 2007 no mejoraron sus indicadores de bienestar durante el periodo 1993-2007 más que el resto de municipios del país con características similares» (Arellano Yanguas 2011: 213).
} 
$82,4 \%$ y $86,5 \%$ en 2005 , a $90,5 \%$ y $100 \%$ en 2010 , en los mismos departamentos y respectivamente (INEI 2006-2010). En términos generales, se precisan datos semejantes en cuanto a insatisfacción con servicios públicos, saneamiento, salud y educación.

Cruzando la información consignada por Arellano y las percepciones recogidas por el Latinobarómetro y la Enaho, se concluye que no se identifican mejoras concretas ni perceptivas. Por el contrario, podría hablarse incluso de un significativo incremento en la sensación de insatisfacción general. Esta paradoja entre el aumento de políticas redistributivas y la insatisfacción creciente es lo que trataré de aclarar a continuación.

\section{Alternativas a la interpretación redistributiva. Propuesta de un marco conceptual}

Con la propuesta de análisis que presento, quiero interpretar los conflictos desde una perspectiva diferente. Para ello parto de la hipótesis de que el problema central no es de carácter redistributivo. A tal efecto, expondré sucesivamente tres modelos, y mostraré comparativamente las ventajas y las limitaciones de cada uno, así como el modo en que pueden complementarse para estructurar un marco conceptual comprehensivo de interpretación y análisis de conflictos. Lo que de ello resulte tendrá el estatus de una hipótesis de trabajo teóricamente fundada, pero cuya eficacia deberá todavía terminar de ser corroborada en la práctica mediante trabajo de campo.

\subsection{E1 modelo democrático-deliberativo}

La más importante ventaja de este modelo es que enfrenta directamente la habitual lectura redistributiva del conflicto mediante la incorporación de una dimensión adicional representada por la necesidad de deliberación público-política. Este modelo coloca en primer plano el rol insustituible que tienen los derechos de participación política en la vida 
ciudadana (Rawls 1996: 318-319). La deliberación es el espacio de resolución de problemas sociales y de interpretación colectiva de las necesidades de las partes en disputa. Ello evita la imposición unilateral de ciertas nociones de desarrollo y bienestar. Así, por ejemplo, en el caso de la minería, el modelo deliberativo evitaría que nociones de desarrollo vinculadas con la acumulación de riqueza que luego debe ser distribuida a través de impuestos sean propuestas como la única interpretación posible. Que los asuntos de justicia básica hayan sido decididos sin la participación de todos los involucrados significa que el ejercicio de la libertad comunicativa es nulo. Solo la deliberación abre la posibilidad de que los descontentos y demandas puedan ser expresados, interpretados, discutidos y resueltos (Elster 1997; Habermas 1992).

Según esta concepción, el poder -que es aquí esencialmente entendido como poder comunicativo- es algo intrínsecamente positivo que debe ser salvaguardado mediante la garantía del ejercicio de las libertades políticas. En este sentido, se afirma que estas no pueden ser prescindibles, ya que aseguran un rasgo esencialmente humano: la necesidad de acción y discurso. A diferencia de lo que ocurre con una visión puramente instrumental (o redistributiva), en este modelo las libertades políticas no pueden ser reemplazadas o intercambiadas por otros bienes. La concepción utilitarista-instrumental se encuentra a la base de las tendencias asistencialistas y populistas, según las cuales lo que importa es un resultado determinado de antemano. Por lo tanto, a esta aproximación le daría exactamente lo mismo si pudiera obtenerse un resultado similar por otras vías -esto es, sin deliberación-.

Como ya se vio, es precisamente esta última perspectiva la que parece haber cobrado protagonismo en los debates actuales en torno a la minería. Al partir del hecho de que entre las partes existen luchas de intereses claramente definidas, se asume unilateralmente que los llamados grupos «antimineros» demandarían exclusivamente el control de recursos o de territorio, así como la posesión de otros bienes similares, escasos y cuantificables. Entonces -se deduce-, si pudiera lograrse un cierto grado 
de bienestar material que satisfaga algunas de tales demandas, el diálogo y con ello el ejercicio de los derechos políticos se volverían innecesarios y hasta superfluos. En efecto, como se indicó, desde después de las primeras negociaciones entre el Estado y las compañías mineras durante el gobierno de Fujimori hasta la actualidad, las soluciones recomendadas para el problema del descontento social han estado del lado del aumento progresivo de los impuestos y de un esfuerzo del Estado por incrementar el canon por extracción minera, de modo que la responsabilidad por satisfacer las demandas de los pobladores recaiga enteramente en el lado de los gobiernos regionales, los cuales - se afirma- no son capaces de administrar los cuantiosos recursos obtenidos. En otras palabras, se crea la ilusión de que se trata únicamente de un problema de deficiente redistribución de recursos y de planeamiento y aplicación de políticas públicas.

Para el modelo deliberativo, la inclusión no significa otra cosa que la posibilidad de tomar parte equitativamente en los procesos discursivos una vez que ha surgido un desacuerdo. Es decir, poder «ingresar» en las esferas que el sistema político debe poner a disposición de todas las personas para que manifiesten su disconformidad y deliberen en torno a cualquier tipo de asunto que las afecte.

Según esto, el conflicto surgiría cuando las partes perciben que estos mecanismos no funcionan. Es decir, cuando al tener una demanda que esperan poder expresar y tratar públicamente, los actores no encuentran las vías adecuadas para que esto sea posible, para que su voz sea oída y sus aportes dignos de ser considerados significativos. Un conflicto social no es, entonces, sin más, síntoma de que un grupo percibe una situación dada como injustificada o carente de validez. Ello constituye el caso normal en una sociedad saludable. El conflicto surge más bien -y ello se aplica con precisión al caso de la minería-allí donde hay la percepción de que los mecanismos que deberían canalizar las demandas no existen, son obstaculizados o están deformados. Por tal motivo, los conflictos sociales suelen interpretarse como reclamos frente al Estado y no simplemen- 
te como enfrentamientos entre bandos contrarios. Naturalmente, esa situación se agrava cuando una de las partes considera que dicho mal funcionamiento se da intencionalmente, con el propósito de beneficiar a uno de los involucrados en el problema. En el caso que estamos analizando, esto ocurre cuando el Estado -instancia que en cuanto a garantías procedimentales debería jugar un rol neutral y proteger la equidad- se identifica con las compañías mineras.

A pesar de todas sus virtudes, este modelo presenta una importante limitación, que puede resumirse como sigue: para que la deliberación funcione correctamente y conduzca a mejoras en la calidad de vida de las personas, se requiere una serie de exigentes condiciones materiales, sociales y culturales, así como un grado mínimo de desarrollo de ciertas capacidades argumentativas. Pero resulta que muchas de estas condiciones coinciden precisamente con aquel estado de cosas que la deliberación debería propiciar. Al no darse dichas condiciones, la deliberación no puede ser realizada, con lo cual la situación previa de desventaja permanece o se agrava ${ }^{6}$.

La revelación de estos límites no implica rechazar sin más la deliberación política como medio de resolución de problemas. Se trata más bien de mostrar la necesidad de ser completamente consecuentes con ella e incorporar un análisis complejo de las condiciones que permitan su correcta realización. Los dos siguientes modelos que presento permiten precisamente esto.

\subsection{E1 modelo del desarrollo humano y el enfoque de capacidades}

De acuerdo con la posición defendida por Amartya Sen, el poder es la capacidad de una persona de realizarse de modo integral a lo largo de

\footnotetext{
${ }^{6}$ Sobre el problema de la «circularidad» o «círculo vicioso» en las teorías deliberativas de la democracia, puede consultarse: Bohman (1996: 123 y ss); Forst (2007: 294297); Fraser (2007: 328-235).
} 
su vida, según los parámetros que ella misma considera valiosos. Esta realización involucra diversas formas de agencia social (esto es, el cumplimiento de diversas «funciones» en diferentes contextos sociales). Según la definición de Sen, «capacidad» es «una clase de poden» que opera como una suerte de catalizador individual que convierte recursos «multipropósito» en bienestar real (Sen 2009: 19). Por «recurso» se entiende aquí todo aquello que de un modo u otro es susceptible de ser «distribuido» o repartido (desde oportunidades o libertades básicas hasta recursos materiales como dinero, bienes de consumo o incluso infraestructura, escuelas, etc.). Estos «bienes multipropósito», que los defensores de una solución redistributiva consideran como el objeto central de las políticas de Estado, no son, por decirlo así, valiosos «por sí mismos». Su valor no es intrínseco, sino que les viene dado en función de cómo son utilizados por las personas que los reciben. Pero para ser utilizados se requiere lo que Sen llama «capacidad» de conversión, algo que puede variar notablemente de grupo a grupo y de persona a persona y que los defensores de la redistribución no suelen toman en cuenta, influidos como están por un criterio de desarrollo y progreso establecido a priori, poco permeable a la deliberación y, por lo mismo, ciego a la diferencia.

En relación al proceso democrático, Sen comparte la noción básica de la democracia deliberativa, según la cual el uso público de la razón es consustancial a la idea de desarrollo humano, puesto que es un componente insustituible para la constitución de la identidad y la expresión de las vivencias y exigencias reales de las personas. Es decir, sin deliberación sobre los problemas es imposible saber qué debe ser (re)distribuido y de qué modo hacerlo, puesto que sin tales procesos de «discusión y formación colectiva de la opinión y la voluntad» (Habermas 1992) no se puede llegar a ser consciente de las verdaderas necesidades, demandas y potenciales aportes significativos del otro. Esto es claro en el caso que nos ocupa, por lo que este modelo podría ofrecer una explicación convincente de la aparente contradicción implicada en la percepción simultánea del alto índice de insatisfacción de la población y de los extraordinariamente positivos indicadores de ingresos estatales provenientes de la actividad minera. 
Pero si bien en una comunidad política moderna es impensable el desarrollo humano sin el ejercicio de la deliberación, aquel comprende a la vez otras muchas formas de interacción que no necesariamente dependen o se restringen a la praxis político-argumentativa. La democracia, entendida como un proceso que se da a lo largo de la vida, se refiere, pues, al conjunto de prácticas e instituciones que aseguran tal desarrollo pleno. De este modo, el éxito de una sociedad solo puede medirse en función del desarrollo integral de los individuos que la conforman, lo cual solo es posible considerando todos los contextos sociales en que este desarrollo se da (Sen 2009: 9).

De cualquier modo, esta posición permite concebir la exclusión en un sentido más amplio que el primer modelo, ya que queda referida a los obstáculos de la vida social que no solo bloquean el acceso a las esferas deliberativas, sino, más en general, impiden el ejercicio pleno del poder concebido como capacidad de desarrollarse en todas las esferas relevantes de socialización. Esta posibilidad de realización (esta «inclusión», podríamos decir), no obstante, no se comprende simplemente en términos de posesión de bienes (esto es, aquello que puede ser distribuido, medido, cuantificado), sino, sobre todo, en términos de ejercicio efectivo de la libertad y la capacidad real para alcanzar el bienestar y perseguir lo que uno tiene buenas razones para valorar. En esa medida, las políticas públicas que se concentran únicamente en el aspecto redistributivo de bienes o recursos no serían suficientes para establecer cuándo se puede garantizar un auténtico desarrollo humano, ya que por lo general dejan fuera de consideración las desigualdades existentes en los índices de conversión de tales recursos en funcionamiento efectivo.

A pesar de su aproximación multidimensional al problema del desarrollo, este modelo no ofrece una explicación satisfactoria de la problemática del surgimiento del descontento y el conflicto social. Y esto es así simplemente porque no establece con claridad cuáles son las expectativas normativas que los agentes pueden considerar como vulneradas y ante las cuales pueden exigir, dado el caso, una reivindicación. En otras pala- 
bras, si bien esta aproximación establece qué es aquello que las personas podrían legítimamente desear como requisitos para el cumplimiento de sus planes de vida, no queda igualmente claro por qué y bajo qué criterios podrían exigirle de manera legítima a «alguien» (sea este «alguien» un grupo de personas, instituciones, empresas o el Estado mismo) que fomente (o no impida) tal realización. Por ello, al no haber una justificación para esta exigencia, no habría un motivo convincente para la demanda y el reclamo social.

Dicho esto, presentaré a continuación el tercer modelo, el cual incorpora importantes elementos de análisis para llenar los vacíos del recién expuesto enfoque de las capacidades, en especial aquellos referidos a la interpretación de las motivaciones detrás de los conflictos sociales y a la articulación de las diversas formas de reconocimiento exigidas por una comprensión integral del desarrollo humano. Este modelo logra, por lo demás, establecer un vínculo orgánico entre la perspectiva de los bienes comunes y una concepción del poder social que se desliga de premisas provenientes tanto de las teorías de la elección racional como de la tradición del contrato social.

\subsection{E1 modelo del reconocimiento y el poder social constructivo}

Este modelo se concentra en las diversas formas de participación social requeridas para el desarrollo pleno de la personalidad y la identidad. En cuanto a su base informacional, esta perspectiva no se halla muy lejos de la propuesta de Sen, en la medida en que también reconoce que libertad y desarrollo requieren un conjunto multidimensional de esferas de interacción. Una de las ventajas de este modelo frente al de Sen es, no obstante, la reconstrucción histórico-genealógica de las bases normativas sobre las cuales las sociedades capitalistas han constituido sus diferentes ámbitos de participación. Con esta reconstrucción se espera ofrecer una aproximación realista a la «gramática» de las demandas y luchas sociales, tal como estas se dan en contextos cotidianos de interacción (Honneth 1992). 
La noción de poder asociada comúnmente a esta aproximación tiene un alcance más amplio que la del primer modelo. Ambas concepciones se asemejan en que reconocen al poder una función esencialmente intersubjetiva. A diferencia de la noción de ese primer modelo, sin embargo, el poder aquí no es necesariamente sinónimo o causa directa de un consenso.

Foucault (1997) mejor que nadie ha captado el sentido original que tiene esta noción de poder social constructivo. Para él, el poder se encuentra a medio camino entre la violencia y el consenso. El poder, de este modo, ni actúa directamente sobre la conducta de un otro, forzando sus acciones, ni promueve necesariamente el acuerdo normado y racional. El poder actuaría más bien sobre las estructuras que condicionan el comportamiento posible. Y puede ejercer esta función «pastoral», de guía de la conducta, precisamente porque configura el espacio social en el cual los sujetos actúan, espacio que por principio no es de tal o cual individuo, sino que es común. En este sentido puede decirse que el poder es la capacidad de nombrar, de categorizar, de establecer significados y valoraciones a los conceptos con los que nos representamos el mundo. Con esto, solo de aquellos que han tomado parte en su constitución-que disponen de suficiente «capital simbólico»- puede decirse que son seres autónomos, en la medida en que no están siendo «sujetos» por un orden en el cual no se reconocen y frente al cual permanecen como simples espectadores sin influencia (Bourdieu 1985; Rancière 1998).

Según lo anterior, el proceso democrático -el encargado de garantizar legítimamente que las personas tomen parte en la creación del mundo social- es en este modelo idéntico al ejercicio del poder social. Tal proceso consiste en que todos los involucrados sean partícipes del capital simbólico que permite categorizar el mundo común y establecer los significados y valoraciones sociales. Puesto que el modo en que está constituido lo social condiciona las oportunidades reales de los individuos e influye, además, sobre el modo en que se ejercen las libertades políticas, el problema primario no sería el del rediseño de los mecanismos político- 
deliberativos para permitir un mejor «ingreso» (a la manera de la formación de «mesas de diálogo» entre las partes enfrentadas), sino más bien el del modo en que se dan las relaciones de poder en las prácticas e instituciones reales (Fraser 2007). La inclusión, así, tiene aquí que ver con la posibilidad de ser capaces de contribuir a la creación del mundo común y de definir qué es considerado como valioso o relevante, razonable o significativo. El ejercicio simétrico de esta forma de poder social es posible mediante relaciones de reconocimiento intersubjetivo al interior de diversas esferas de participación e interdependencia. Estas formas de reconocimiento permiten que las personas se realicen de modo autónomo, al tiempo que se reconocen como coautoras de la realidad social común.

De esta manera, el conflicto puede explicarse a partir de las luchas por el reconocimiento en cada una de las esferas de interacción en que los individuos esperan legítimamente algún tipo de consideración (Honneth 1992). Se habla propiamente de conflicto cuando estas demandas se plantean ante un orden institucional dado que sirve de sustento material a algún tipo de práctica identificada por los propios actores como injusta $\mathrm{O}$ no justificada. En este sentido, tales luchas pueden conducir a la exigencia de transformación de ciertas estructuras que bloquean el desarrollo pleno y autónomo de la identidad, en cuya creación -se asume- los demandantes no han tomado parte $y$, por tanto, no se reconocen.

Este modelo permite una mejor clave de explicación del caso de la minería, ya que se concentra en la pregunta por la múltiple motivación moral y normativa de las demandas, luchas y conflictos sociales desde la perspectiva de los propios actores. Las preguntas que contempla son: ¿Qué es aquello que los individuos perciben como vulnerado? ¿En relación a qué expectativas se sienten traicionados al grado de propiciar un enfrentamiento con órdenes y estructuras vigentes? ¿En qué medida tales reclamos pueden considerarse justificados? (Honneth 2003). La respuesta que este modelo sugiere -y que se sustenta en evidencia empírica- es que el descontento conducente al conflicto se produce 
cuando son traicionadas ciertas expectativas de reconocimiento que las personas creen legítimamente merecer. Si bien estos reclamos proceden de diversas fuentes - que corresponden a las distintas esferas en las que se puede esperar algún tipo de reconocimiento social-, la fuerza normativa implicada en la necesidad de «retribución» o «corrección del daño» (no solo de redistribución) es lo que permite llamar a todas estas demandas «morales». La normatividad de las demandas procede, por lo demás, de la normatividad inherente a las instituciones de la sociedad en la que los actores sociales se desenvuelven y que de una u otra manera -tácita o explícitamente- se aceptan como universalmente vinculantes (Honneth 2003).

Así, la pregunta por la base motivacional y su legitimidad es perfectamente pertinente en el caso de los conflictos que nos ocupan, puesto que se trata de saber qué es exactamente lo que se reclama en la oposición «antiminera». Es decir, ¿pueden explicarse los reclamos solo en términos de una mayor distribución de bienes? La pregunta que motiva las dudas al respecto es: ¿Por qué ante la promesa de mayores recursos y bienestar total no existe, entonces, conformidad, sino todo lo contrario? A partir de lo expuesto y confrontándolo con la realidad, pareciera sensato afirmar que las demandas no se refieren simplemente a la exigencia, estratégicamente motivada, de la posesión individual de mayores bienes o recursos; esto es, no se trata exclusivamente de un reclamo por una recolección y redistribución más justa de las riquezas mediada por el Estado. Las demandas -como se observa en las encuestas- se suelen referir a otras muchas formas de participación social. Son causadas por múltiples razones, pues multidimensionales son las esferas de interacción en las cuales puede esperarse reconocimiento recíproco.

Consecuentemente, la libertad se entiende en este modelo como la posibilidad de desarrollar sin obstáculos y plenamente la personalidad mediante la participación en todas las esferas de interacción reconocidas y sancionadas normativamente en una sociedad dada. O, dicho de otro modo, como la capacidad de actuar con orientación a la constitución de 
la identidad y de perseguir de modo autónomo lo que uno tiene razones para valorar (Sen 2000: caps. 2, 3). Como se ha visto, entonces, el conflicto se produciría cuando los individuos experimentan la existencia de obstáculos -expresados bajo la forma de ciertas prácticas, instituciones o estructuras sociales, pero también de medidas o políticas estatales concebidas de modo utilitario-que dificultan su realización plena como seres libres; esto es, cuando algo bloquea injustificadamente su capacidad de agencia en el sentido antes indicado.

\section{Consideraciones finales}

A partir de lo visto, estoy ahora en condiciones de sacar algunas conclusiones que puedan aportar una clave de lectura alternativa a la tradicional interpretación redistributiva de demandas y conflictos, la cual -me parece-comparte la intuición básica de la perspectiva de los bienes comunes. Y es que la clara contradicción entre, de un lado, el aumento de políticas económicas de orientación redistributiva y la construcción de estructuras en las cuales se refleja esta misma lectura y, de otro lado, el aumento de los conflictos y la cada vez mayor insatisfacción, así como el mantenimiento del malestar social y la percepción de ineficiencia y favoritismo estatal, parece mostrar, en efecto, la ineficacia del actual marco interpretativo.

Como hemos observado, las demandas que suelen encontrarse a la base de los conflictos sociales poseen una naturaleza más bien compleja, al estar referidas a la insatisfacción de determinadas expectativas en diversas dimensiones de interacción y participación social necesarias para la constitución de la identidad y el desarrollo sin obstáculos de la personalidad. Por ello resulta contraintuitivo pretender reducir estas demandas a una simple exigencia redistributiva. La carencia de reconocimiento, de oportunidades y de capacidades necesarias para tal desarrollo multidimensional es interpretada por los propios actores como una ofensa moral que se expresa en forma de padecimiento, malestar e indignación al ex- 
perimentar el incumplimiento de una larga serie de compromisos normativos tácita o explícitamente asumidos por el Estado.

La interpretación de tales deficiencias simplemente como una necesidad de recursos materiales que podría satisfacerse mediante la aplicación de ciertas políticas de redistribución representaría, según hemos visto, una imposición categorial que contradice los principios elementales de la deliberación democrática y de una autocomprensión autónoma. De este modo, partir de una tal unidimensionalidad no resuelve en absoluto el problema. Dicha imposición configura una realidad en la que los afectados actúan de modo unilateral y deforma tendenciosamente lo que las personas podrían legítimamente esperar y exigir de la sociedad y del Estado. Con ello - como ya hemos observado- se produce un ocultamiento de otros muchos factores relevantes para la autorrealización de los actores sociales.

Las demandas y conflictos aumentan porque se cree estar reclamando la satisfacción de una necesidad que ha sido ya interpretada de antemano como la única posible ${ }^{7}$, cuando en realidad no se ha llegado todavía a identificar las causas reales del malestar y la insatisfacción, ya que estas han sido convenientemente ocultadas, deformadas o interpretadas de modo inauténtico. Al luchar por algo que se cree legítimo sin serlo realmente, es de esperar que la sensación de insatisfacción no mengüe, sino más bien aumente, y se exprese en conflictos cada vez más extremos, cuya naturaleza parece a primera vista inexplicable y ante los cuales solo queda el recurso oficial de llamarlos «irracionales» o, en el mejor de los casos, ideológicamente «politizados».

Como ya mencioné, estas reflexiones tienen un carácter especulativo en la medida en que constituyen una hipótesis de trabajo que deberá

\footnotetext{
${ }^{7}$ Esto es, la búsqueda de beneficios materiales concretos e inmediatos y no la transformación estructural en el sentido en que los modelos antes descritos la entienden.
} 
todavía ser cotejada con casos específicos. Para ello sería necesario contar con análisis empíricos, cuya recolección ciertamente excede los propósitos de esta investigación. Si algún mérito tiene este trabajo, radica, en todo caso, en haber presentado un marco interpretativo que puede servir de guía a dicho análisis y, además, de mostrar su validez, al diseño de políticas públicas más adecuadas para canalizar y solucionar conflictos sociales.

\section{Referencias bibliográficas}

Arellano Yanguas, Javier

2013 «Minería y conflicto en Perú: sembrar minerales, cosechar una avalancha de piedras». En: Bebbington, A. (ed.), Industrias extractivas: conflicto social y dinámicas institucionales en la región andina. Lima: IEP / Cepes / Grupo Propuesta Ciudadana, pp. 151-184.

2011 ¿Minería sin fronteras?: conflicto y desarrollo en regiones mineras del Perú. Lima: IEP / PUCP / UARM.

Arendt, Hannah

1958 The Human Condition. Chicago: University of Chicago Press.

BOHMAN, James

1996 Public Deliberation. Pluralism, Complexity, and Democracy. Cambridge: MIT Press.

Bourdieu, Pierre

1985 «The Social Space and the Genesis of Groups». En: Theory and Society, vol. 14, $\mathrm{N}^{\circ}$ 6, pp. 723-744.

Casuso, Gianfranco

2013 Dimensionen der Exklusion. Sozialphilosophische Beiträge zu Demokratie und Macht. Friburgo y Munich: Karl Alber.

s. f. «What Inclusion excludes. Elements for a Critical and SocialPhilosophical Theory of Exclusion» (manuscrito inédito). 
Una propuesta para el análisis de conflictos sociales en términos de deliberación, agencia y reconocimiento. El caso de la minería en el Perú

Cohen, Joshua

1989 «Deliberation and Democratic Legitimacy». En: Hamlin, A. y P. Pettit (eds.), The Good Polity. Oxford: Blackwell, pp. 17-34.

Cotter, Julio

2011 «Capitalismo y democracia en el Perú: la tentación autoritaria». En: Pásara, Luis (ed.), Perú ante los desafíos del siglo XXI. Lima: PUCP, pp. 519-555.

Crocker, David

2005 «Sen and Deliberative Democracy». En: Kaufman, A. (ed.), Capabilities Equality. Basic Issues and Problems. Nueva York: Routledge, pp. 295-359.

De Echave, J. y V. Torres

2005 Una estimación de los efectos de la minería en los indices de pobreza en Perú. Lima: CooperAcción.

Defensoría del Pueblo

2013 Reporte de conflictos sociales. Lima: Defensoría del Pueblo.

2009 Reporte de conflictos sociales. Lima: Defensoría del Pueblo.

ELSTER, Jon

1997 «The Market and the Forum: Three Varieties of Political Theory». En: Bohman, J. y W. Rehg (eds.), Deliberative Democracy: Essays on Reason and Politics. Cambridge: MIT Press, pp. 4-33.

FORST, Rainer

2007 «First Things First: Redistribution, Recognition and Justification». En: European Journal of Political Theory, vol. 6, N³, pp. 291-304.

Foucault, Michel

1997 «The Subject and Power». En: Faubion, J. (ed.), Michel Foucault. Power. Nueva York: The New Press. 
Fraser, Nancy

2007 «Identity, Exclusion, and Critique». En: European Journal of Political Theory, vol. 6, $\mathrm{N}^{\circ}$ 3, pp. 305-338.

HABERMAS, Jürgen

1996 «Drei normative Modelle der Demokratie». En: Die Einbeziehung des Anderen. Frankfurt: Suhrkamp, pp. 277-292.

1992 Faktizität und Geltung. Frankfurt: Suhrkamp.

Honneth, Axel

2010 «Das Gewebe der Gerechtigkeit». En: Das Ich im Wir. Berlín: Suhrkamp, pp. 51-77.

2003 «Redistribution as Recognition. A Reply to Nancy Fraser». En: Fraser, N. y A. Honneth (eds.), Redistribution or Recognition? Londres: Verso.

1992 Kampf um Anerkennung. Frankfurt: Suhrkamp.

\section{INEI}

2006-2010 «Encuesta Nacional de Hogares, Enaho». Lima: INEI.

LAdEN, Anthony

2007 «Reasonable Deliberation, Constructive Power and the Struggle for Recognition». En: Van den Brink, B. y D. Owen (eds.), Recognition and Power. Axel Honneth and the Tradition of Critical Social Theory. Cambridge: Cambridge University Press, pp. 270-289.

\section{LATINOBARÓMETRO}

1995-2011 Informe Latinobarómetro. Santiago de Chile: Corporación Latinobarómetro. Fecha de consulta: 27/9/2013. <http:// www.latinobarometro.org/latino/LATAnalizeIndex.jsp $>$.

MACKINNON, Catharine

1991 Toward a Feminist Theory of State. Nueva York: Harvard University Press. 
Una propuesta para el análisis de conflictos sociales en términos de deliberación, agencia y reconocimiento. El caso de la minería en el Perú

\section{MACROCONSULT}

2008 Impacto de la actividad minera en el Perú. Lima: Macroconsult.

PASTOR, Cinthya

2012 «Pobreza, desigualdad de oportunidades y políticas públicas en el Perú». En: Pobreza, desigualdad de oportunidades y politicas públicas en América Latina. Alemania: Sopla, pp. 136-146. Fecha de consulta: 5/5/2013. <http://ipe.org.pe/documentos/pobreza-desigualdad-de-oportunidades-y-politicas-publicas-en-el-peru $>$.

Pastor, Cinthya; Ernesto Ángeles; Patricia Pérez y Miguel Palomino

2012 «Efecto de la minería sobre el empleo, el producto y la recaudación en el Perú». Lima: IPE. Fecha de consulta: 10/10/2013. $<$ http://ipe.org.pe/documentos/efecto-de-la-mineria-sobre-elempleo-el-producto-y-la-recaudacion-en-el-peru-0>.

\section{Patrón, Pepi}

s. f. «Power and Deliberative Participation in Sen's Capability Approach» (manuscrito inédito).

RANCIÈRE, Jacques

1998 Disagreement. Minnesota: University of Minnesota Press.

RAWLS, John

2001 Justice as Fairness. A Restatement. Cambridge: Harvard University Press.

1996 Political Liberalism. Nueva York: Columbia University Press.

SEN, Amartya

2009 The Idea of Justice. Cambridge: Harvard University Press.

2000 Development as Freedom. Nueva York: Anchor.

1995 Inequality Reexamined. Cambridge: Harvard University Press. 


\section{Gianfranco Casuso}

THE ECONOMIST

2008 «Peru: To the Barricades. The Politics of Non-stop Protest». En: The Economist, 6 de diciembre, $\mathrm{N}^{\circ}$ 51. Fecha de consulta: 5/10/ 2013. <http://www.economist.com/node/12725161>.

Young, Iris

2000 Inclusion and Democracy. Oxford: Oxford University Press.

1997 «Diference as a Resource for Democratic Communication». En: Bohman, J. y W. Rehg (eds.), Deliberative Democracy. Essays on Reason and Politics. Cambridge: MIT Press, pp. 383-406. 


\title{
Minería e inversión social en turismo. Miradas desde la ética, el desarrollo y la sostenibilidad
}

\author{
Carlo Brescia y Viviana Quea \\ Asociación Civil Vasos Comunicantes
}

La definición de conceptos como desarrollo, responsabilidad o bienestar es un ejercicio que no escapa a la subjetividad de quien la construye. Ella dependerá siempre de la cultura del individuo o del grupo que la elabora, por lo cual, toda definición de este tipo de conceptos depende de un espacio y de un tiempo determinados y expresa ideologías e intereses particulares. Se trata de construcciones culturales - dinámicas y muchas veces polisémicas- que guían políticas y prácticas cuyos fines son tan contradictorios que pueden ir de la sustentabilidad humana a la autodestrucción de nuestra especie.

La mirada reflexiva y abierta desde la que se abordan en este artículo la minería y la inversión social en el turismo se basa en las siguientes definiciones:

- Ética ambiental: reflexión racional y práctica sobre los problemas derivados de la relación del hombre con la naturaleza.

- Sostenibilidad: capacidad de un sistema para mantenerse dinámico y estable a lo largo del tiempo; tiene varias dimensiones, como la social, la económica y la ambiental. 
- Desarrollo: proceso de cambio continuo en un sistema desde una situación inicial hacia otra que se considera mejor; incluye, entre otras, dimensiones como la social, la económica, la política, la cultural y la institucional.

- Desarrollo sostenible: desarrollo que toma en cuenta las necesidades del presente sin comprometer la capacidad de las futuras generaciones para satisfacer las de la generación actual.

- Impacto ambiental: consecuencia que se da cuando una política, programa o actividad produce una alteración -favorable o desfavorable- en el medio ambiente o en alguno de sus componentes.

- Impacto social: efecto que tiene lugar cuando una política, programa o actividad provoca una alteración -favorable o desfavorableen el medio social o en alguno de sus componentes.

Tomando en cuenta estas definiciones, debemos buscar un desarrollo sostenible que maximice los impactos positivos -sociales y ambientales- y reduzca o mitigue los negativos. Nuestro planeta tiene límites, razón por la cual se deben tomar decisiones basadas en información confiable y, en lo posible, objetiva para que, a través de las políticas y prácticas diseñadas e implementadas a nivel público y privado, nuestra sociedad prospere.

Sin embargo, lo que se advierte en la realidad es muy diferente. A nivel nacional e internacional, lo que prevalece es el paradigma de la modernización basado en la libre e infinita extracción, transformación y consumo masivo de materias primas limitadas, sobre la base de una ideología capitalista según la cual la sostenibilidad de la civilización humana no depende del mantenimiento de los ecosistemas regionales y planetarios. Este supuesto ha tenido y tiene en la actualidad graves consecuencias ambientales, tales como la reducción de la biodiversidad, la contaminación de los factores ambientales (suelo, agua, aire) y sus ciclos, la degradación ambiental y el cambio climático. En cuanto al impacto social, la competencia por los cada vez más escasos recursos naturales - una cons- 
tante en la historia de la humanidad- ha provocado guerras entre países y conflictos internos cuyas principales víctimas son siempre quienes tienen menos poder.

En este contexto, nuestro país sigue promoviendo la inversión en industrias extractivas -que generan innegables y voluminosos ingresos a las arcas públicas-al tiempo que se posiciona, en la mente de los peruanos, como un país hecho para el goce de los turistas. ¿Es posible, a través del desarrollo de las industrias extractivas y del sector turístico, lograr un desarrollo sostenible para el país? Consideramos que sí es posible, pero para ello se tienen que dar ciertas condiciones complementarias, entre las que resalta la inversión pública en el desarrollo del principal recurso del país -el humano- a través del fortalecimiento de sectores como la educación, la salud, el medio ambiente, la cultura, la agricultura y la justicia. Es claro que, en términos generales, se ha avanzado muy poco en estos ámbitos.

\section{La responsabilidad en la minería}

\subsection{Minería y responsabilidad social empresarial}

¿Cómo hacemos para continuar con la actividad minera de manera que, en lugar de poner en riesgo el equilibrio social, cultural y ambiental, contribuya a responder a las necesidades de cada una de estas esferas? Muchas empresas mineras han intentado responder de manera estratégica a esta pregunta a través de prácticas de responsabilidad social empresarial (RSE) en su frente externo, sobre todo con proyectos de inversión social. Es importante advertir que, por lo menos a nivel de las grandes y medianas empresas, la implementación de programas de este tipo ha aumentado desde los años 1990. Pero, ¿qué hay más allá de los títulos y de las fotos de gerentes que regalan computadoras a niños andinos sonrientes? ¿Qué criterios subyacen al diseño de los proyectos sociales? ¿Qué 
impacto tienen estos en las poblaciones con las que se ejecutan? ¿Las personas son consultadas sobre lo que quieren, pueden y necesitan cuando se diseñan los proyectos?

\subsection{Inversión social para el desarrollo: errores comunes en los proyectos}

Si bien es innegable que hay un avance en la voluntad de construir una mejor relación entre las empresas y el entorno, no es extraño constatar en la actualidad que muchos de los proyectos de inversión social minera empiezan a tener fallas similares a las que presentan los proyectos públicos de la cooperación internacional y de ONG. ¿Por qué fallan los proyectos sociales? Veamos detenidamente qué ocurre cuando una empresa minera decide hacer un proyecto de este tipo.

Por un lado, hay que considerar que, si la empresa lleva a cabo sus proyectos sociales directamente a través de un área de gestión social o de una gerencia de relaciones comunitarias (o, en los casos más burdos, por medio de un departamento de marketing o de relaciones públicas), sabe de antemano que entra en un terreno que no es de su expertise, lo cual constituye un error estratégico grave. Si, en el mejor de los casos, la empresa busca a un aliado experto en el tema, es probable que, al carecer de conocimientos sobre la gestión de proyectos sociales, no tenga criterios claros para elegirlo ni lineamientos adecuados para hacer un seguimiento a su gestión.

Por otro lado, a esta primera dificultad operativa en la gestión de proyectos sociales, se suma quizás la más grave: la falta de una visión adecuada. Cuando se pretende trasladar la lógica extractivista a los proyectos sociales, el fracaso está garantizado, ya que se aplican al ámbito social criterios y prácticas inapropiados, tales como: exigencia de plazos cortos para los diagnósticos iniciales, vehemencia por resultados rápidos, planteamiento de indicadores inadecuados a los temas sociales, imposi- 
ción de objetivos inspirados en necesidades operativas de la empresa, asignación de personal inexperto e improvisación.

Finalmente, la falta de consistencia es otro de los grandes problemas de la inversión social minera. En efecto, el principio de gestión según el cual «ensucio por aquí pero construyo por allá» ha estado en la base de muchos proyectos. De allí el deterioro de la imagen pública de las empresas y el descrédito del concepto mismo de RSE, considerado como un maquillaje publicitario o como un medio para silenciar a las poblaciones en el corto plazo y conseguir licencias sociales rápidas y susceptibles de explotación mediática.

\subsection{El turismo como temática de moda en los proyectos mineros de inversión social}

Dado que muchos de los proyectos mineros se desarrollan en zonas alejadas de las ciudades y con gran potencial turístico, las empresas optan por el turismo como una de las áreas temáticas favoritas para sus proyectos de inversión social. Lo mismo se aprecia en el caso de las empresas de hidrocarburos y construcción. De esta manera aparecen proyectos de turismo vivencial, turismo rural comunitario, turismo gastronómico y turismo cultural. Algunos de ellos incluyen capacitación para la gestión de operadores de turismo, hoteles, restaurantes y transportes, así como asesoría para el desarrollo del servicio. Otros, más básicos, se limitan a actividades de marketing, tales como el desarrollo de marcas de destino, mercadeo de rutas o circuitos temáticos, promoción de artesanía local, publicaciones, etc. En cualquiera de estos casos, el horizonte de intervención suele ser limitado, de manera que el tiempo no alcanza para conseguir cambios sostenibles. Son raros los proyectos que duran más de tres años.

El problema del horizonte nos remite a uno más profundo, el de la visión: la concepción misma de los proyectos suele ser éticamente cuestionable. Veamos dos ejemplos actuales. 
- Caso 1. Hay una playa atractiva frente a las plataformas de una empresa petrolera. La comunidad de pescadores ya no tiene de qué vivir, pues cada vez hay menos peces en el mar como consecuencia de la actividad petrolera. Se propone, entonces, la creación de una ruta gastronómica para que los pescadores desempleados puedan beneficiarse de la afluencia turística de verano. Sin embargo, no se considera que si no hay peces no puede haber ruta gastronómica. Tampoco se toma en cuenta que la población carece de agua potable y de sistemas de saneamiento, ni que no está preparada para asumir una lógica de negocio. ¿No sería acaso más relevante invertir en agilizar los trámites para que se corrijan los problemas de agua en la zona? ¿O desarrollar con el Estado un programa de educación en salud reproductiva para contrarrestar el problema del embarazo adolescente en estas comunidades? ¿O, lo que es más difícil, repoblar la zona impactada para restablecer la oferta de peces del mar, base de la economía de la comunidad?

- Caso 2. Una empresa busca licencia social para su proyecto hidroeléctrico. Para ello, tiene que negociar sobre una petición de la comunidad, que exige la construcción de un hotel de cinco estrellas al lado de sus fuentes termales con el argumento de que se quiere atraer al turismo y competir con Machu Picchu. La empresa decide contratar consultores para la realización del proyecto. Nuevamente, se pierde de vista que una exigencia de este tipo es el resultado de una mala relación inicial con la comunidad y del deficiente mapeo de actores sociales, que no permitió advertir que un grupo de falsos ingenieros había entusiasmado a la comunidad con expectativas infundadas sobre sus recursos naturales para obtener beneficios de la empresa. ¿Quién iría a esos baños termales ubicados en una zona inaccesible? ¿Quién va a trabajar en ese hotel? ¿No sería mejor evaluar primero la viabilidad de tal iniciativa y compararla con otras opciones de mayor impacto social? 
Casos como estos invitan a pensar en cuáles son los criterios éticos y técnicos que conducen a tan malas decisiones. ¿Es correcto esperar que una comunidad que apenas puede sostenerse y que no logra acceder a los servicios básicos se maquille para atender a turistas? El turismo en contextos de necesidad extrema no funciona. De poco sirve que la esposa de un pescador prepare un plato gourmetpara un visitante extranjero si ella y sus hijos sufren de desnutrición crónica y no tienen acceso a agua potable. Tampoco es útil levantar un hotel de cinco estrellas o bungalós rurales si la propia población duerme en condiciones infrahumanas o carece de servicios básicos. Y de nada sirve poner en valor un sitio arqueológico para el turismo si la comunidad que lo alberga no conoce su historia ni aprecia su valor.

Si se trata de invertir en turismo, debe hacerse con el fin de contribuir a solucionar problemas más estructurales que tendrán relación con esa actividad: agilizar los trámites para la construcción de carreteras, habilitar agua potable y desagüe, y promover la educación sobre el patrimonio cultural y natural. En otras palabras, deben realizarse proyectos vinculados al turismo, pero que respondan ante todo a las necesidades de las personas que estarán a cargo de la actividad.

\section{Antamina en Conchucos y su proyecto de intervención en turismo Vive Conchucos}

Para ilustrar estas ideas con un caso práctico, veamos qué ocurre con el proyecto Vive Conchucos en Áncash, financiado principalmente por la empresa Antamina. Concentrémonos en el área geográfica del distrito de Chavín de Huántar.

La compañía minera Antamina es una empresa de capitales extranjeros que opera desde hace más de diez años en la región. Se beneficia de los contratos de estabilidad tributaria y no paga regalías mineras al Esta- 
do peruano, razón por la cual representa la mayor contribución al PBI en Áncash. Sus operaciones de extracción tienen lugar en el distrito de San Marcos, en la provincia de Huari.

Chavín de Huántar es un distrito ubicado en una zona con una historia de más de tres mil años. Allí se encuentra el centro ceremonial de Chavín de Huántar, reconocido como Patrimonio Cultural de la Humanidad por la Unesco desde 1985. Dado que este distrito se encuentra dentro del área de influencia de la compañía minera Antamina, Chavín de Huántar recibe transferencias por canon minero, que el año 2013 fueron de 38 millones de soles (Prensa Regional 2013), por lo cual se ubica en el tercer lugar entre los distritos y provincias que reciben más canon minero en la Región Áncash ${ }^{1}$.

Sin embargo, en Chavín de Huántar la tasa de desnutrición es 49\% en niños y niñas menores de cinco años (Midis 2012), mientras en el departamento de Áncash la media es 27,7\% y a nivel nacional, 22,1\% (INEI 2013); y en cuanto a educación, en la provincia donde se ubica Chavín de Huántar los resultados en comprensión lectora y matemática en los niños de segundo grado de primaria solo son satisfactorios para 10\% de los estudiantes (Ministerio de Educación 2012). Sin embargo, una parte significativa de los presupuestos para obras (al menos 10\%) se gasta en prácticas de corrupción entre las autoridades municipales y las empresas de construcción. En conclusión, al igual que en otros distritos del proyecto Vive Conchucos, Chavín de Huántar tiene problemas sociales y, al mismo tiempo, uno de los mayores presupuestos del país a nivel local, al menos desde el año 2005.

\footnotetext{
${ }^{1}$ Los otros distritos y provincias que más canon reciben en Áncash son: distrito de San Marcos (139 millones de soles), provincia de Santa (44 millones), distrito de Nuevo Chimbote (31 millones), provincia de Huari (30 millones), provincia de Huaraz (18 millones).
} 


\subsection{E1 proyecto}

El objetivo del proyecto Vive Conchucos es «generar ingresos y empleo en el Valle de Conchucos» ${ }^{2}$. Es financiado por Antamina y por Perú Opportunity Fund y la institución ejecutora es Swisscontact, entidad suiza de cooperación para el desarrollo con presencia en el Perú desde el año 1966 y dedicada a promover el desarrollo económico, social y ambiental con el objetivo de insertar a las personas en la vida comercial local ${ }^{3}$.

\subsection{Vive Conchucos: ¿qué es y qué encontramos en cuanto a responsabilidad social empresarial?}

Lo que se puede constatar en la actualidad en Áncash es la voluntad de una empresa con antecedentes de efectos sociales y ambientales negativos ${ }^{4}$ de llevar a cabo un proyecto que tenga un impacto

${ }^{2}$ Cf. Swisscontact (s. f. b): «[...] así como incentivar el desarrollo sostenido y responsable del turismo, a través de la promoción de iniciativas empresariales y la generación de un entorno favorable entre los diferentes socios estratégicos. Para tal fin promueve la calidad de servicios turísticos en los distritos de Chavín, San Marcos y Huari en Áncash, a través de la mejora continua de los negocios ya existentes y el impulso de nuevos emprendimientos de acuerdo a la vocación de la zona y con ajuste a las necesidades del mercado actual y potencial, implementando en paralelo la estrategia de promoción del destino mediante herramientas de marketing».

${ }^{3}$ Cf. Swisscontact (s. f. a): «El foco de sus intervenciones está puesto en el fortalecimiento de las cadenas de valor locales y globales, a través de proyectos que buscan beneficiar a poblaciones en pobreza o en alto riesgo social, en ámbitos urbanos y rurales. Como parte de su estrategia de intervención, establece alianzas con entidades de cooperación, actores públicos y privados y, en particular, empresas comprometidas con el desarrollo comunitario y la competitividad del territorio donde operan».

${ }^{4}$ Piénsese, por ejemplo, en el caso de la reubicación involuntaria en el distrito de San Marcos (2000), investigado por Grade, y en casos socioambientales, como la filtración en el túnel de decantación de la presa de relaves en la comunidad de Ayash (2006), la volcadura del camión de un contratista que transportaba asfalto líquido en el distrito de Aquia (2007) y el derrame de metales pesados del mineroducto que va de Yanacancha a Huarmey en el distrito de Cajacay (2012). 
positivo en una de sus áreas de influencia más vulnerables. Para ello ha convocado a Swisscontact. De acuerdo con lo que se ha podido constatar a través de la experiencia directa del proyecto, de su descripción en la página web y del testimonio de algunos de sus stakeholders, el proyecto debe enfrentar las siguientes limitaciones:

\section{A. Está centrado principalmente en actividades de promoción, pues busca atraer a más visitantes hacia la zona de Conchucos.}

Aquí subyace la ingenua premisa de que más turismo equivale a más desarrollo, lo cual se parece mucho a la lógica anacrónica e irresponsable del «chorreo». Si bien se necesitan más visitantes para dinamizar la economía local mediante el turismo, es importante hacerse las siguientes preguntas: ¿Cuál es la capacidad de carga de los lugares visitados, especialmente de sitios arqueológicos como Chavín o la laguna de Purhuay? Y, en general, ¿cuál es el límite de cambio aceptable en la cultura y en el paisaje de sitios que son objeto de promoción turística? Estas consideraciones técnicas son fundamentales en un proyecto de esta naturaleza; sin embargo, tales preguntas siguen esperando respuesta.

B. El proyecto trabaja principalmente con emprendedores de restaurantes y hospedajes, pues la intervención se enfoca en la mejora de su marketing así como en el fortalecimiento de los servicios turísticos.

El desarrollo de los microemprendedores es importante, sin embargo, cabe preguntarse cómo Swisscontact, la contraparte ejecutora, realiza las intervenciones. Se debe considerar que un cambio en la cultura de trabajo local no es fácil, sobre todo si se trata de poblaciones con origen mayormente rural y que están poco familiarizadas con una cultura de negocios. ¿Cómo convencer a un emprendedor de un restaurante de que no debe tener perros en la 
cocina o de que es importante incluir una oferta vegetariana en su carta de menú? Estos elementos importantes para la competitividad de un restaurante en términos turísticos chocan con prácticas culturales largamente arraigadas en los operadores. ¿Es realista esperar, entonces, que con intervenciones de 45 días se implementen mejoras en los servicios?

Es imprescindible pensar primero en una negociación y en una sensibilización, partiendo de la idea de que el turista no es simplemente un sujeto cargado de dólares y reconociendo la distancia cultural. Esto es necesario para la construcción de un equilibrio. Si se busca una mejora permanente de los servicios, también habría que ayudar a los negocios a cumplir con las normas básicas que les corresponden. Pero se encuentra que, después de más de tres años de presencia de Swisscontact en la zona, los negocios que originalmente fueron parte de la intervención aún no están formalizados ni reúnen las condiciones de sanidad básicas para que la Dirección General de Salud Ambiental (Digesa) autorice su funcionamiento.

La mejora continua implica el seguimiento de la implementación de cambios previamente consensuados entre asesores y emprendedores. Si las intervenciones se limitan a capacitaciones esporádicas de poca duración y sin ningún acompañamiento, no habrá pedagogía que perdure ni que pueda traer verdaderas transformaciones. No se trata de vender más, sino de vender mejor y de manera sostenible: de hacer negocios responsablemente.

\section{E1 proyecto no se ocupa de problemas transversales al turis- mo ni coordina con actores claves de la zona}

El turismo es una actividad compleja que requiere el trabajo coordinado de una pluralidad de actores: desde los proveedores de servicios públicos (carreteras, agua, desagüe, seguridad, salud, edu- 
cación) hasta los de servicios privados (operadores). Una percepción compartida por los vecinos del distrito respecto al proyecto es que este no tiende puentes hacia actores relacionados con la gestión del patrimonio cultural y social, tales como directores de colegios, responsables de sitios arqueológicos, museos y otros servicios. Si no se convoca a estos actores, difícilmente se podrán abordar temas importantes como el fortalecimiento de la identidad, la protección del patrimonio cultural e inmaterial y su inclusión en la agenda educativa local. El resultado es que mucha gente de la zona vive de espaldas a su patrimonio, no lo cuida, lo depreda y sigue procesos de alienación cultural que se convierten en una amenaza para aquello que constituía en principio un atractivo turístico.

Un proyecto de turismo bien pensado tendría que partir de lo que la gente necesita. Si la población local se siente ajena a su patrimonio y no directamente involucrada en su cuidado, el proyecto no llegará a dar frutos. Los microemprendedores son importantes, pero son solo un componente de un sistema más vasto.

Si bien se podrían señalar otras debilidades referidas a la implementación del proyecto Vive Conchucos, aquí nos hemos concentrado en las que corresponden a problemas de diseño, es decir, de enfoque del proyecto, que pudieron y debieron resolverse en instancias anteriores a su implementación. Si se pretende que el proyecto sea sostenible, su enfoque deberá ir más allá de los aspectos estrictamente económicos e incorporar aspectos culturales, ambientales y sociales.

\section{Mitos e implicancias éticas de la inversión social en turismo}

Es importante que toda empresa minera que desea impulsar proyectos en el ámbito del turismo tome en cuenta los siguientes mitos sobre el turismo en función de consideraciones éticas y prácticas: 


\section{A. El turismo es la industria sin chimeneas.}

Se suele tomar como cierta la afirmación según la cual el turismo es una «industria sin chimeneas», así como la idea de que representa una alternativa de bajo riesgo para sacar a las poblaciones vulnerables de la pobreza. Se olvida que el turismo puede tener un impacto negativo en el medio ambiente debido a la emisión de gases de efecto invernadero, la generación de residuos sólidos y efluentes líquidos, la producción de alteraciones culturales y ambientales e incluso la depredación de recursos.

\section{B. E1 turismo sacará a la gente de la pobreza.}

Es necesario comprender que mientras no se enfrenten los problemas sociales de salud, educación y nutrición ningún proyecto de turismo contará con las bases sólidas necesarias para asegurar su sostenibilidad.

Es absurda la pretensión de transformar en dos años a una pequeña comunidad de tejedoras en una próspera empresa exportadora de tejidos artesanales o la de consolidar a un grupo de agricultores altoandinos en poco tiempo como contratistas de construcción para una empresa minera, sin considerar que los cambios culturales requieren procesos largos y que no todos los convocados para los proyectos desean implicarse realmente en ellos. El problema de la pobreza no se va a resolver porque existan turistas. En realidad, ellos constituyen uno de los requisitos mínimos para que empiece a haber un desarrollo turístico.

\section{Un recurso turístico basta para generar un flujo turístico.}

En muchas ocasiones, las comunidades y los creadores de proyectos creen que el hecho de contar con espacios como una plaza de 
toros, un sitio arqueológico abandonado o una catarata asegurará, con un poco de promoción, la presencia de turistas. Se trata de una ilusión, ya que para que esto ocurra se requieren muchos procesos previos y complementarios. Un recurso turístico solo se convierte en un atractivo o en un producto cuando cuenta con un valor agregado, lo que implica su puesta en valor así como el desarrollo de servicios y de una marca, es decir, inversión.

\section{En un país como el Perú se puede experimentar con las personas.}

Si una empresa promueve proyectos de turismo sin tener en cuenta lo que esto significa, alimenta falsas expectativas y retrasa inútilmente la confrontación con la verdad. Es mejor decir a los pobladores de una comunidad: «su fuente termal está demasiado alejada de los circuitos turísticos» $\mathrm{O}$ «su sitio arqueológico no es suficientemente atractivo para competir con otro que está mejor conservado», en lugar de alimentar en ellos expectativas sobre proyectos que no serán sostenibles o que presentan, desde su concepción misma, limitaciones en la visión, el presupuesto y su alcance. Si se crean expectativas infundadas en la población, habrá frustración y descontento: condiciones para la generación de conflictos.

\section{E. Nosotros sabemos lo que es mejor para la gente.}

Urge dejar de mirar a las personas como necesitadas y como beneficiarios pasivos, es decir, romper las relaciones verticales que muchos proyectos establecen desde el inicio. Es mejor escuchar, negociar, aprender y orientar. Con frecuencia se contratan «expertos en turismo», pero la visión de muchos de ellos está sesgada por los intereses del sector de hotelería y de agencias de viaje, cuyos representantes no saben cómo lidiar con problemas de desarrollo, negociación, conflicto, interculturalidad, patrimonio o gestión ambiental. 
La creencia según la cual el experto en turismo sabe lo que es mejor para el desarrollo de la gente es falsa.

Si a esto se suma la arrogancia de quien procede de la capital y tiene instrucción superior, se construye una distancia que implica la negación del otro por parte del creador del proyecto. Así, este último se muestra incapaz de comprender las sutilezas culturales que son claves para el desarrollo del proyecto e impone sus propias ideas sobre lo que él cree que será mejor para la gente.

\section{F. El turismo siempre es una buena opción.}

Llegamos al mito más peligroso. El turismo no siempre es la opción más legítima y pertinente. El éxito de los proyectos de esta actividad depende de muchos factores. Es posible que algunos entornos socioculturales se encuentren más preparados para su desarrollo debido a la existencia de personas que ya acuden al lugar, condiciones de infraestructura y servicios adecuados, gestores locales comprometidos con una visión de desarrollo sostenible y población dispuesta a involucrarse en diversas tareas con responsabilidad. Pero se debe considerar que se trata de proyectos complejos que pueden generar una gran cadena de expectativas.

Si, por ejemplo, se piensa en un proyecto de turismo rural comunitario entre cuyos componentes se encuentra la construcción de casas rurales y de un mirador, habrá que confirmar que el suelo donde se construyan no sea un desmonte, que el diseño sea armónico respecto del entorno, que haya accesibilidad y seguridad para llegar al lugar, que exista un flujo turístico que justifique la inversión y también un equipo humano que se ocupe de los servicios. Ninguna infraestructura funciona sola. 
4. Hacia un modelo de gestión inclusivo y sostenible: propuesta para una inversión social con responsabilidad social

A continuación, proponemos un conjunto de consideraciones que las empresas mineras deben tener en cuenta para invertir en lo social de manera responsable.

A. Un discurso honesto y profesional desde el inicio.

Los proyectos no deben obedecer a una visión del desarrollo que atropelle la cultura local o la someta a intereses de terceros. Deben partir de la propia gente, es decir, ser participativos en su diseño y a lo largo de todo el proceso. El desarrollo tiene que ver con personas; estas deben participar activamente, desde el inicio, en los proyectos que se les proponen.

B. Una mirada holística al manejo de los programas sociales acorde con la realidad local y que aporte a la construcción de ciudadanía.

Es necesario vincular la intervención de los proyectos con temas más estructurales: educación, salud, alimentación, identidad cultural y sostenibilidad. Puede ocurrir que el turismo no sea la inversión directa más aconsejable sino el resultado de la maduración de otros procesos en una comunidad. La investigación por parte de un equipo interdisciplinario con experiencia efectiva es clave en este sentido.

C. Un buen diagnóstico inicial para conocer a la gente y su situación.

En el afán de obtener resultados rápidamente, se suele apresurar o incluso obviar la elaboración de diagnósticos iniciales y el reco- 
nocimiento de campo. Se debe, por el contrario, invertir tiempo en conocer realmente quién es quién, qué necesidades hay, qué expectativas existen, qué quiere realmente la gente y qué capacidades puede desarrollar. Este diagnóstico puede adoptar diferentes formas: estudio de línea base, estudio de impacto social o diagnóstico participativo.

\section{Empoderación de los stakebolders para la sostenibilidad y pro- moción de la apropiación de los proyectos.}

La apropiación de un proyecto - requisito fundamental para su sostenibilidad-se da cuando las personas se sienten representadas en él, cuando sienten que hay un interés genuino en ellas, cuando se ve un impacto directo en su calidad de vida. Las personas cuidan su piscigranja porque les proporciona ingresos y asegura la alimentación de sus hijos; cuidan su chacra porque les da alimentos; cuidan su casa porque les costó construirla; cuidan su proyecto porque se sienten involucradas en él. Si una empresa se limita a distribuir donaciones y confía a otros las tareas vinculadas a un proyecto, entonces no hay empoderamiento: no hay transferencia de conocimientos ni identificación. De allí la importancia de involucrar a los diferentes actores, promover la formación de redes, delegar tareas, plantear metas comunes, hacer alianzas y concertar esfuerzos. Aunque este camino tome más tiempo, asegura un proceso estratégico, menos riesgoso, rentable y ético.

\section{E. Conocimiento del mercado (en el caso de proyectos de inver- sión social para el desarrollo de cadenas productivas).}

Se implementan los proyectos productivos, se capacita a la población, se desarrolla toda la cadena de valor y luego aparece la pregunta: ¿quién va a comprar estos cuyes, artesanías, mermeladas, ponchos?, ¿quién va a utilizar estos servicios de turismo rural comunitario? Para evitar este tipo de situaciones, es importante partir de la 
identificación de un mercado para luego evaluar si realmente habrá relación entre oferta y demanda. Se trata de evitar las expectativas frustradas y, con ello, las semillas de nuevos conflictos.

\section{F. Monitoreo con indicadores realistas y plazos razonables.}

Desde el inicio, es importante evaluar las capacidades de un proyecto. Para ello es imprescindible definir y medir indicadores cuantitativos y cualitativos que permitan saber si el proyecto avanza de acuerdo a lo planeado.

\section{Conclusión}

La responsabilidad implica tener cuidado en el momento de la toma de decisiones, sobre todo cuando estas pueden afectar de manera significativa la vida de poblaciones actuales y futuras así como la de ecosistemas naturales. La verdadera responsabilidad va más allá de las leyes nacionales o internacionales, porque resulta de un proceso de reflexión en el cual los sectores público y privado evalúan el impacto social y ambiental de sus políticas a corto, mediano y largo plazo.

El concepto «minería sostenible» es en sí mismo cuestionable, ya que ninguna actividad económica basada en la extracción de recursos limitados puede mantenerse indefinidamente. Sugerimos, en su lugar, «minería responsable» para designar la actividad de aquellas empresas de extracción de minerales que van más allá de las leyes y buscan contribuir realmente al desarrollo sostenible de la comunidad y del país en el que operan.

Del mismo modo, el término «turismo sostenible» no corresponde a la realidad de un sector económico que, al menos en el Perú, implica un alto consumo de combustibles fósiles para el traslado de los turistas. 
Puesto que en el escenario actual los combustibles fósiles tienen un fin y aún no se han hallado fuentes de energía alternativas que los reemplacen, dicho turismo no constituye una actividad sostenible a largo plazo. Por lo tanto, sugerimos el uso del término «turismo responsable» para referirnos a aquellas empresas que contribuyen al desarrollo sostenible a través del turismo.

Para que el desarrollo sostenible basado en el sector turístico sea posible, es necesario que se formalicen quienes realizan actividades en él, que mejoren los derechos laborales de los trabajadores y que sus actividades se enmarquen dentro del paradigma de la sostenibilidad. También es imprescindible reconocer que la actividad turística puede tener un impacto negativo a nivel social y ambiental. Y, si se considera al turismo como un eje del desarrollo, de ninguna manera puede ser el principal.

Teniendo en cuenta lo anterior, ¿no debería una minería responsable invertir en otros sectores más críticos? Está demostrado que el sector empresarial requiere de emprendedores. Las personas que lo son reúnen una serie de capacidades. En la medida en que no todos están llamados a desarrollar la visión necesaria para el manejo de una empresa, ¿no sería mejor invertir en programas relacionados con la educación, la salud y la alimentación? Desde nuestro punto de vista, la experimentación social por parte de una empresa privada no es ética.

En el caso de la empresa Antamina y el distrito Chavín de Huántar, es cierto que el centro ceremonial de Chavín de Huántar es un recurso turístico muy importante. Pero también lo es que en el distrito ya existe mucho dinero gracias al canon minero. ¿La mina debe financiar actividades dentro del sector turístico que tengan como objetivo atraer dinero de afuera para una parte de la población? ¿O debería apoyar más bien actividades que busquen una mejor redistribución de la riqueza para toda la población? Pensamos que la segunda opción es la más estratégica y ética para la empresa y para la población. 


\section{Bibliografía}

INEI

2013 «Encuesta Demográfica y de Salud Familiar 2012, Nacional y Departamental, Endes». Lima: INEI.

Midis, Ministerio de Desarrollo e Inclusión Social

2012 «Lineamientos para la gestión articulada intersectorial e intergubernamental orientada a reducir la desnutrición crónica infantil, en el marco de las políticas de desarrollo e inclusión social». Directiva $\mathrm{N}^{\circ}$ 004-2012-MIDIS.

Ministerio de EduCACIÓN

2012 «Evaluación censal de estudiantes». Lima: Ministerio de Educación.

Prensa Regional

2013 «Distribución por provincias y distritos de la región Áncash del canon minero». Huaraz: Prensa Regional

<http://www.invierteenhuaraz.com.pe/prensa/regionales/58regionales /8746-distribucion-por-provincias-y-distritos-de-laregion-ancash-del-cano-minero $>$.

SWISSCONTACT

s. f. a «Swisscontact Perú». < http://www.swisscontact.org.pe/content/ bienvenidos>.

s. f. b «Vive Conchucos». Swisscontact Perú.

$<$ http://www.swisscontact.org.pe/turismo-sostenible/vive-conchucos>. 


\section{Siglas usadas}

ANDA Asociación Nacional de Anunciantes

Ceads Consejo Empresarial Argentino para el Desarrollo Sostenible

Conar Consejo Nacional de Autorregulación Publicitaria

Digesa Dirección General de Salud Ambiental

Enaho Encuesta Nacional de Hogares

FIFA Federación Internacional de Fútbol Asociado

Grade Grupo de Análisis para el Desarrollo

Indecopi Instituto Nacional de Defensa de la Competencia y de la Protección de la Propiedad Intelectual

INEI Instituto Nacional de Estadística e Informática

ONG Organización no gubernamental

PBI Producto bruto interno

RSE Responsabilidad social empresarial

Unesco Organización de las Naciones Unidas para la Educación, la Ciencia y la Cultura

WBCSD World Business Council for Sustainable Development 